\title{
Prenatal transmission of scrapie in sheep and goats: A case study for veterinary public health
}

\author{
D.B. Adams* \\ 24 Noala Street, Aranda, ACT 2614, Australia
}

\begin{abstract}
Unsettled knowledge as to whether scrapie transmits prenatally in sheep and goats and transmits by semen and preimplantation embryos has a potential to compromise measures for controlling, preventing and eliminating the disease. The remedy may be analysis according to a systematic review, allowing comprehensive and accessible treatment of evidence and reasoning, clarifying the issue and specifying the uncertainties. Systematic reviews have clearly formulated questions, can identify relevant studies and appraise their quality and can summarise evidence and reasoning with an explicit methodology. The present venture lays a foundation for a possible systematic review and applies three lines of evidence and reasoning to two questions. The first question is whether scrapie transmits prenatally in sheep and goats. It leads to the second question, which concerns the sanitary safety of artificial breeding technologies, and is whether scrapie transmits in sheep and goats by means of semen and washed or unwashed in vivo derived embryos. The three lines of evidence derive from epidemiological, field and clinical studies, experimentation, and causal reasoning, where inferences are made from the body of scientific knowledge and an understanding of animal structure and function. Evidence from epidemiological studies allow a conclusion that scrapie transmits prenatally and that semen and embryos are presumptive hazards for the transmission of scrapie. Evidence from experimentation confirms that semen and washed or unwashed in vivo derived embryos are hazards for the transmission of scrapie. Evidence from causal reasoning, including experience from other prion diseases, shows that mechanisms exist for prenatal transmission and transmission by semen and embryos in both sheep and goats.
\end{abstract}

Keywords: Goat, Prenatal, Scrapie, Sheep, Transmission.

\section{Introduction}

Control and prevention of communicable diseases such as scrapie is beyond reach when knowledge about of pathways of transmission is absent, or when false knowledge is accepted or true knowledge is rejected. The demonstration of prenatal transmission of scrapie in sheep (Garza et al., 2011; Rubenstein et al., 2012; Foster et al., 2013; Spiropoulos et al., 2014) is of major importance in this regard because it establishes a firm basis for the control and possible elimination of scrapie. False rejection of prenatal transmission in these circumstances will deny benefits to animal health and welfare, preclude some analytical perspectives on atypical scrapie, and limit possibilities for understanding all neurodegenerative diseases in all species. Emerging concerns for scrapie and animal health are the conservation of rare breeds of sheep and goats, safeguards against incursions of scrapie into scrapie-free regions and the potential for an interspecies jump as occurred with bovine spongiform encephalopathy (BSE) and people (Ulvund, 2008).

Past views about scrapie downplayed or rejected prenatal transmission. Parry (1983) claimed that transmission of an infectious agent played little part in the natural history of scrapie and that the disease propagated from generation to generation through inheritance of the scrapie trait. Thirteen years later a review by Hoinville (1996) summarised scrapie as an infectious disease with a genetic influence on the incubation period and where horizontal transmission eclipsed maternal transmission; that is, transmission from dam to offspring in utero or in the immediate postpartum period. Later reviews (Detwiler and Baylis, 2003; Jeffrey and Gonzalez, 2007; Fast and Groschup, 2013) conclude that the available evidence supported scrapie transmission after birth and not before birth. These conclusions are reflected in influential operational guides such as those from the World Organisation for Animal Health (OIE, 2011) and Animal Health Australia (2009), which include explicit statements on transmission, and in current recommendations for the sanitary safety of artificial insemination and embryo transfer in sheep and goats (IETS, 2010).

Given the significance of matters mentioned above, the recent experimental demonstration of prenatal transmission of scrapie in sheep merits exposure to possible refutation by testing its agreement or not with evidence from (1) epidemiological, field and clinical studies; (2) experimentation, and (3) causal reasoning, 
which refers to inferences made from the body of scientific knowledge. This work investigates the three streams of evidence and the method employed follows that of a systematic review rather than an expert, narrative or other sort of review (Petticrew and Roberts, 2006). A review qualifies as systematic 'if it is based on a clearly formulated question, identifies relevant studies, appraises their quality and summarizes the evidence by use of explicit methodology' (Khan et al., 2003). A systematic review allows for scrutiny of arguments, encourages reasoned refutation, and facilitates the progressive refinement of knowledge.

\section{Questions for review}

Two explicit questions are addressed. The first question is: Does scrapie transmit prenatally in the sheep and goat? Prenatal refers to the period from oogenesis to parturition. The second question is tied to the definition of hazard in the Terrestrial Code of the World Organisation for Animal Health (OIE, 2015). The OIE defines a hazard as a biological, chemical or physical agent in, or a condition of, an animal or animal product with the potential to cause an adverse health effect. In the present case, the biological agent is the scrapie agent, the animal products are in vivo derived embryos and semen and the adverse health effect is scrapie that may be transmitted to sheep or goats by means of in vivo derived embryos or semen. So, the explicit question is: Does scrapie transmit in sheep and goats by means of semen and washed or unwashed in vivo derived embryos? Washing refers to the procedure recommended by the International Transfer Society (IETS, 2010).

\section{The prion theory}

Credence is given to the prion theory for causation of the transmissible spongiform encephalopathies or TSEs (Prusiner, 1998, 2013), which include scrapie in sheep and goats. The prion theory has explanatory and predictive power and has demonstrated its value for understanding scrapie in sheep (Hunter, 2007). For instance, scrapie disease can be controlled by selection of sheep carrying the variant of the prion gene that codes for resistance to scrapie (Goldmann, 2008). In addition, the presence of misfolded prion protein (designated as $\mathrm{PrP}^{\mathrm{Sc}}$ ), which reflects a fundamental event in prion diseases, underpins the immunochemical tests for diagnosing scrapie (Katz et al., 1992; Miller et al., 1993) and the more recent PMCA (protein misfolding cyclic amplification) tests (Saa et al., 2005). Prions are infectious agents consisting of a misfolded version of the cellular prion molecule $\left(\mathrm{PrP}^{\mathrm{c}}\right)$ that is encoded by the prion gene sequence (PRNP). Misfolded prion molecules form aggregations and induce a chain reaction whereby malformed $\mathrm{PrP}^{\mathrm{Sc}}$ 'seeds' impose their dysfunctional malformation on functional prion proteins (Caughey et al., 2009; Soto, 2012; Supattapone, 2015). A key consequence is disruption to the nervous system, which eventually results in death.

\section{Access to information}

Relevant studies for review were sought through three Internet databases, which were interrogated with relevant keywords.

The Internet databases were Pubmed of the United States National Institutes of Health: http://www.ncbi.nlm.nih.gov/sites/entrez?db=pubmed, Agricola of the United States Department of Agriculture: http://agricola.nal.usda.gov, and Google Scholar: http://scholar.google.com.au.

A bibliography prepared by the US National Institute of Neurological Diseases (Gibbs et al., 1969) provided access to the literature on scrapie published before 1969 and was noteworthy for its coverage of papers in languages other than English. A monograph on scrapie by Parry (1983) also assisted with coverage of the earlier literature on scrapie. A published account of a seminar on scrapie held in Washington DC in 1964 (Agricultural Research Service, US Department of Agriculture, 1966) provided insights into thinking about scrapie at that point in time.

\section{Procedures for identifying, marshalling and} evaluating evidence

Three sources of evidence (Fig. 1) were applied to the explicit questions under review. These sources relate to experimentation (designed studies), the epidemiology of scrapie and to causal reasoning. Collectively, they can exhaust Hill's nine criteria for causation (Hill, 1977).

Experimentation refers to studies undertaken with a predetermined design and employing either deliberate infection of animals with the scrapie agent (manipulative studies) or the selection of cohorts of scrapie-infected animals (correlative or observational studies). The soundness of designed studies was evaluated according to a framework compiled from Oehlert (2000) and Ruxton and Colegrave (2006) (see online supporting material below).

Evidence from epidemiology refers to studies of the distribution and determinants of scrapie in sheep populations where systematic records exist. A particular issue is whether the relative risk of scrapie is higher in the offspring of scrapie-infected sires or dams when susceptible genotypes are accounted for. A higher relative risk of scrapie related to sires implicates direct transmission of the scrapie agent in semen. A higher relative risk related to dams implicates prenatal infection with scrapie including transmission of the scrapie agent before implantation. Another issue is that of the infectivity. Porta (2014) defines infectivity as a measure of the ability of a disease agent to establish itself in the host. Infectivity refers to the proportion of a cohort or group that become infected after exposure to an infectious agent such as the scrapie agent. 


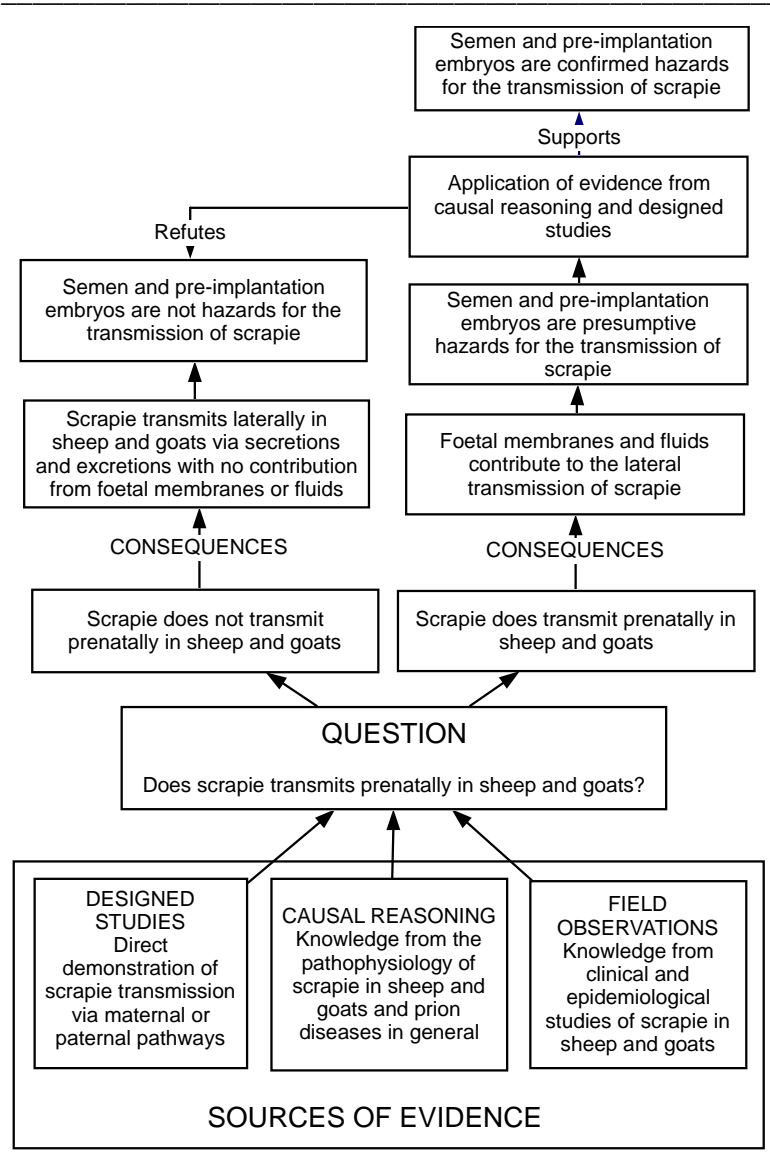

Fig. 1. Diagram showing the three sources of evidence for a systematic review on prenatal transmission of scrapie in sheep and goats.

Causal reasoning, the third source of evidence shown in Fig. 1, refers to inferences from the body of scientific knowledge and particularly knowledge about the aetiology and pathogenesis (i.e. the pathophysiology or disordered physiology) of scrapie in sheep and goats and the transmissible spongiform encephalopathies in general. Kassirer et al. (2009) explain causal reasoning as 'an aspect of the diagnostic process based on the cause-and-effect relations between clinical variables or chains of variables. It is a function of the anatomic, physiologic, and biochemical mechanisms that operate in the normal workings of the [human] body and the pathophysiologic behavior of these mechanisms in disease'.

\section{Hypothesis testing and epistemic uncertainty}

Hypothesis testing on the two explicit question under review involves four alternative conclusions or evaluations that cover the concepts of a type I error (false positive) and a type II error (false negative). The four possible conclusions for prenatal transmission of scrapie or transmission of scrapie via semen or in vivo derived embryos are shown in Table 1. Hansson (2013) points out that type I errors are considered more vexing than type II errors in the 'internal dealings of science'.
On the other hand, type II errors can have severe practical consequences when risks are being managed. A type I error in relation to scrapie may involve unnecessary actions, wasted energy and loss of opportunity. In contrast, a type II error may lead to outbreaks of scrapie, the possibility of propagating epidemics and all the adverse impacts of disease. Conclusions 1 and 2 proceed from the hypotheticodeductive method and refer to clear-cut decisions where a single significant finding can vindicate rejection or otherwise of a given hypothesis. In contrast, Conclusions 3 and 4 relate to assessments that are not clear-cut and depend upon the weight of evidence from multiple sources or the assessment of how the inevitable imperfections in scientific studies may affect the informative value of a given study. They represent epistemic uncertainty (uncertainty as to knowledge) and connect to the reality of clinical reasoning, which requires 'a dogged determination to make adequate decisions based on inadequate information' (Nardone, 1990). Assessments within Conclusions 3 and 4 will come from processes of clinical reasoning (Radostits $e t$ al., 2000; Kassirer et al., 2009), the Hill criteria for causality (Hill, 1977), and explanations from the core disciplines of veterinary science; anatomy, physiology and pathology (Hagan and Smithcors, 1964). Conclusions 1 and 2 classify as nominal scale variables that reflect epistemic certainty according to two categories, 'no' or 'yes' (Bonita et al., 2006). In contrast, Conclusions 3 and 4 reflect epistemic uncertainty (imperfect knowledge) and the implied uncertainty can be considered as an ordinal scale variable. 'An ordinal-scale variable has values that can be ranked but are not necessarily evenly spaced, such as stages of cancer' (US Department of Health and Human Services, 2013). The ordinal scale used in this report for epistemic uncertainty within Conclusions 3 and 4 connects uncertainty to judgements about the strength of evidence for or against prenatal transmission of scrapie and for or against ovine and caprine germ plasm being a hazard for the transmission of scrapie. Grades within the ordinal scale refer to evidence of a strength that is deemed to be extremely weak, weak, marginal, strong or extremely strong.

\section{Statistical analysis}

Statistical analyses were conducted with Acastat ${ }^{\mathrm{TM}}$ Software (AcaStat Software, 43584 Merchant Mill Terrace, Leesburg, VA 20176) or StatPlus:Mac 2009 (AnalystSoft).

\section{Supporting material}

Detailed supporting material for this review is in a freely accessible working document at https://www.researchgate.net/publication/281871577_ Prenatal_Transmission_of_Scrapie_in_Sheep_and_Go ats_A_Case_Study_for_Biosecurity_and_Flock_Healt h. 
Table 1: Hypothesis testing on prenatal transmission of scrapie and transmission of scrapie via semen and in vivo derived embryos and the four conclusions possible.

\begin{tabular}{|c|c|c|c|}
\hline Possible conclusion & Prenatal transmission & $\begin{array}{c}\text { Transmission via semen or } \\
\text { washed in vivo derived embryos }\end{array}$ & Nature of conclusion \\
\hline 1 & $\begin{array}{l}\text { Scrapie does not transmit prenatally } \\
\text { and it is concluded correctly that it } \\
\text { does not transmit in this way. }\end{array}$ & $\begin{array}{l}\text { Scrapie does not transmit via } \\
\text { semen or washed in vivo derived } \\
\text { embryos and it is concluded } \\
\text { correctly that it does not transmit } \\
\text { in this way. }\end{array}$ & $\begin{array}{l}\text { Categorical: Yes or no } \\
\text { answer. }\end{array}$ \\
\hline 2 & $\begin{array}{l}\text { Scrapie does transmit prenatally it is } \\
\text { concluded correctly that it does } \\
\text { transmit in this way. }\end{array}$ & $\begin{array}{l}\text { Scrapie does transmit via semen or } \\
\text { washed in vivo derived embryos it } \\
\text { is concluded correctly that it does } \\
\text { transmit in this way. }\end{array}$ & $\begin{array}{l}\text { Categorical: Yes or no } \\
\text { answer. }\end{array}$ \\
\hline $\begin{array}{l}3 \text { - Possibility of } \\
\text { Type I error (False } \\
\text { Positive) }\end{array}$ & $\begin{array}{l}\text { Scrapie does not transmit prenatally } \\
\text { and it is concluded incorrectly that it } \\
\text { does transmit in this way. }\end{array}$ & $\begin{array}{l}\text { Scrapie does not transmit via } \\
\text { semen or washed in vivo derived } \\
\text { embryos and it is concluded } \\
\text { incorrectly that it does transmit in } \\
\text { this way. }\end{array}$ & $\begin{array}{l}\text { Ordinal scale of evidence } \\
\text { with grades } 1-5 . \\
1 \text { : Extremely weak. } \\
\text { 2: Weak } \\
\text { 3: Marginal } \\
\text { 4: Strong } \\
\text { 5: Extremely strong }\end{array}$ \\
\hline $\begin{array}{l}4 \text { - Possibility of } \\
\text { Type II error (False } \\
\text { Negative) }\end{array}$ & $\begin{array}{l}\text { Scrapie does transmit prenatally and } \\
\text { it is concluded incorrectly that it does } \\
\text { not transmit in this way. }\end{array}$ & $\begin{array}{l}\text { Scrapie does transmit via semen or } \\
\text { washed in vivo derived embryos it } \\
\text { is concluded incorrectly that it } \\
\text { does not transmit in this way. }\end{array}$ & $\begin{array}{l}\text { Ordinal scale of evidence } \\
\text { with grades } 1-5 \text {. } \\
\text { 1: Extremely weak. } \\
\text { 2: Weak } \\
\text { 3: Marginal } \\
\text { 4: Strong } \\
\text { 5: Extremely strong }\end{array}$ \\
\hline
\end{tabular}

Evidence from epidemiological, clinical and field studies of scrapie

Relative risk of scrapie in offspring of scrapie-infected parents

Ten publications involving 14 populations of sheep were found with data relevant to the relative risk of scrapie in the offspring of scrapie-infected parents. Four of these publications have appeared since the pioneering epidemiological analysis by Hoinville (1996) of the incidence of scrapie in the offspring of affected and unaffected sheep. Results from these 14 populations are shown in Table 2. Four populations of sheep came from England, seven from Scotland, two from the United States and one from France. Estimates of relative risk in terms of risk ratios are given in one publication (Redman et al., 2002) and did not require recalculation. Figures for incidence proportions in progeny groups (parents with scrapie versus parents without scrapie) were available in the remaining publications. Relative risks were calculated as risk ratios. Statistical significance is indicated by whether the lower $95 \%$ confidence limit of the risk ratio exceeds one.

The mean, median and range of the relative risk of scrapie in the offspring of scrapie-infected ewes for data collated in Table 2 was 4.0, 2.9, and 0.7 to 12.7 for 13 populations. The mean, median and range of the relative risk of scrapie in the offspring of scrapieinfected rams for data collated in Table 2 was 3.8, 2.4, and 1.2 to 11.3 for 11 populations. Table 2 covers a total of 49,614 sheep. With two exceptions, risk ratios in Table 2 were all above one and were statistically significant according to $95 \%$ confidence limits. The first exception relates to the offspring of scrapieinfected rams in the study of Dickinson et al. (1965). Here, scrapie occurred in two only out of the five rams in the key group. Low numbers of sheep and the use of flock rather than individual histories for the selection of parental groups detract from the power of the study by Dickinson et al. (1965). The other exception was in the study of Gonzalez et al. (2012), which gave a lower confidence limit of 0.7. However, the frequency of scrapie in the offspring of infected dams compared with uninfected dams was significantly higher in this instance according to the Pearson chi-square test $(\mathrm{P}<0.017)$.

Relative risks applying to the offspring of scrapieinfected ewes were significantly greater than those applying to the offspring of scrapie-infected rams, p $<0.05$ by Wilcoxon paired-sample test (Zar, 1996). This statistical significance may not translate to biological significance. Infection of the conceptus as a result of scrapie in the sire will be overshadowed when scrapie is already present in the dam.

Studies of scrapie transmission undertaken in the UK with scrapie free sheep from New Zealand and with scrapie susceptible genotypes confirm that the sufficient cause of scrapie disease is composed of two necessary causes (Houston et al., 2002; Ryder et al., 2004; Foster et al., 2006). 
Table 2. Relative risk of scrapie in offspring of parents with and without scrapie from 11 publications and 14 populations of sheep $(\mathrm{IP}=\mathrm{incidence}$ proportion; $\mathrm{RR}=$ risk ratio; $\mathrm{CI}=$ confidence interval; n.a. = not available).

\begin{tabular}{|c|c|c|c|c|c|c|c|c|c|c|c|c|c|c|c|}
\hline \multicolumn{2}{|c|}{$\begin{array}{c}\text { Population of } \\
\text { sheep* }\end{array}$} & 1 & 2 & 3 & 4 & 5 & 6 & 7 & 8 & 9 & 10 & 11 & 12 & 13 & 14 \\
\hline $\begin{array}{l}\text { No } \\
\text { scrapie } \\
\text { in sire } \\
\text { or dam }\end{array}$ & IP & $26 / 334$ & $5 / 27$ & $5 / 165$ & $53 / 153$ & $18 / 311$ & $26 / 105$ & $\begin{array}{c}111 / 342 \\
\text { for } \\
\text { dam, } \\
45 / 127 \\
\text { for sire }\end{array}$ & $47 / 78$ & n.a. & n.a. & n.a. & n.a. & $\begin{array}{c}58 / 21,907 \\
\text { for dam, } \\
447 / 17,150 \\
\text { for sire }\end{array}$ & $57 / 71$ \\
\hline \multirow{2}{*}{$\begin{array}{c}\text { Scrapie } \\
\text { in dam } \\
\text { only }\end{array}$} & $\begin{array}{c}\mathrm{RR} \\
(95 \% \\
\mathrm{CI})\end{array}$ & $\begin{array}{c}10.4 \\
(2.7- \\
39.5)\end{array}$ & $\begin{array}{c}0.7(0.1 \\
-2.1)\end{array}$ & $\begin{array}{l}12.7 \\
(7.0- \\
23.0)\end{array}$ & $\begin{array}{c}1.9(1.5 \\
-2.4)\end{array}$ & $\begin{array}{l}7.7(7.7 \\
-34.4)\end{array}$ & $\begin{array}{c}1.8(1.0 \\
-3.3)\end{array}$ & $\begin{array}{c}2.5(1.7 \\
-3.8)\end{array}$ & $\begin{array}{c}1.3(1.1 \\
-1.6)\end{array}$ & $\begin{array}{c}3.2 \\
(>1.0)\end{array}$ & $\begin{array}{c}2.9 \\
(>1.0)\end{array}$ & $\begin{array}{c}1.9 \\
(>1.0)\end{array}$ & $\begin{array}{c}3.5 \\
(>1.0)\end{array}$ & $\begin{array}{c}6.0(4.7- \\
7.5)\end{array}$ & $\begin{array}{l}5.7(0.8 \\
-38.6)\end{array}$ \\
\hline & IP & $4 / 8$ & $4 / 38$ & $11 / 33$ & $47 / 76$ & $23 / 46$ & $13 / 31$ & $51 / 82$ & $148 / 201$ & n.a. & n.a. & n.a. & n.a. & $74 / 577$ & $35 / 36$ \\
\hline \multirow{2}{*}{$\begin{array}{c}\text { Scrapie } \\
\text { in sire } \\
\text { only }\end{array}$} & $\begin{array}{c}\text { RR } \\
(95 \% \\
\text { CI })\end{array}$ & $\begin{array}{l}3.8(2.6 \\
-5.7)\end{array}$ & $\begin{array}{c}2.6(1.5 \\
-4.5)\end{array}$ & $\begin{array}{l}6.0(2.6 \\
-13.6)\end{array}$ & $\begin{array}{l}1.2(1.0 \\
-1.3)\end{array}$ & $\begin{array}{l}11.3 \\
(6.3- \\
20.5)\end{array}$ & $\begin{array}{c}1.3(1.1 \\
-1.6)\end{array}$ & $\begin{array}{c}1.5(1.2 \\
-1.8)\end{array}$ & n.a. & $\begin{array}{c}2.4 \\
(>1.0)\end{array}$ & $\begin{array}{c}7.8 \\
(>1.0)\end{array}$ & $\begin{array}{c}1.3 \\
(>1.0)\end{array}$ & $\begin{array}{c}2.1 \\
(>1.0)\end{array}$ & $\begin{array}{c}3.8(2.5- \\
5.8)\end{array}$ & n.a. \\
\hline & IP & $24 / 68$ & $22 / 32$ & $32 / 70$ & $24 / 65$ & $57 / 124$ & $50 / 129$ & $76 / 170$ & n.a. & n.a. & n.a. & n.a. & n.a. & $22 / 232$ & n.a. \\
\hline \multirow{2}{*}{$\begin{array}{c}\text { Scrapie } \\
\text { in sire } \\
\text { and } \\
\text { dam }\end{array}$} & $\begin{array}{c}\text { RR } \\
(95 \% \\
\text { CI })\end{array}$ & $\begin{array}{c}83.0 \\
(20.4- \\
337.4)\end{array}$ & $\begin{array}{c}1.4(1.0 \\
-2.0)\end{array}$ & $\begin{array}{c}6.8(3.0 \\
-15.4)\end{array}$ & $\begin{array}{c}2.4(1.8 \\
-3.2)\end{array}$ & $\begin{array}{c}27.4 \\
(13.6- \\
55.1)\end{array}$ & $\begin{array}{l}7.3(2.5 \\
-20.7)\end{array}$ & n.a. & n.a. & $\begin{array}{c}3.3 \\
(>1.0)\end{array}$ & $\begin{array}{c}6.1 \\
(>1.0)\end{array}$ & $\begin{array}{c}2.0 \\
(>1.0)\end{array}$ & $\begin{array}{c}2.8 \\
(>1.0)\end{array}$ & n.a. & n.a. \\
\hline & IP & $30 / 32$ & $19 / 46$ & $33 / 52$ & $18 / 21$ & $48 / 56$ & $14 / 18$ & n.a. & n.a. & n.a. & n.a. & n.a. & n.a. & n.a. & n.a. \\
\hline
\end{tabular}

*Data published by:- 1: Parry (1962); 2: Dickinson et al. (1965); 3: Gordon (1966); 4: Dickinson et al. (1974); 5: Parry (1983); 6 and 7: Hourrigan et al. (1979); 8: Elsen et al. (1999); 9 - 12: Redman et al. (2002); 13: Hoinville et al. (2010); 14: Gonzalez et al. (2012).

n.a.: Not available. 
These necessary causes are the exposure to the scrapie agent and the possession of a scrapie-susceptible genotype in at-risk sheep. Hence, higher relative risks in the offspring of scrapie-infected parents will result from the action of both necessary causes.

The question is the degree to which prenatal transmission contributes to the overall incidence of infection and the nature of the biological relationship that allows for transmission. Conclusion 4 applies and higher relative risks of scrapie in the progeny of scrapie infected parents provide strong evidence that scrapie transmits prenatally.

Two publications were identified for sheep where estimates of relative risks of scrapie infection in the offspring of scrapie-infected parents take account of the transmission of genetic susceptibility as determined by laboratory testing of DNA for variants of the prion gene (Elsen et al., 1999; Hoinville et al., 2010). In doing so, the two publications weigh heavily towards prenatal transmission being a contributor to the relative risks in Table 2. Conclusion 4 can thus be upgraded. Higher relative risks of scrapie in progeny in this situation provide extremely strong evidence that scrapie transmits prenatally.

Elsen et al. (1999) investigated a scrapie outbreak in a flock of hyper-prolific Romanov sheep in southern France. In this outbreak, 1,015 animals were exposed to scrapie, and 304 died from the disease between April 1, 1993 and May 1, 1997. Susceptibility genotypes were determined from blood samples. Epidemiological analysis used survival times and the Cox or proportional hazards model, which is applicable to survival times when several possible causal factors of disease may operate simultaneously (Friedman, 2004). A significantly increased incidence of scrapie in the offspring of scrapie-affected ewes $(p=0.021$ and $\mathrm{p}=0.001$ for the susceptible genotypes of lambs) was observed when the confounding effect of transmitted susceptibility was controlled.

The second publication describing relative risks associated with scrapie-infected parents, and which used laboratory testing of DNA to account for the transmission of genetic susceptibility, is that of Hoinville et al. (2010). The study covers 38 flocks of sheep, a total of 981 cases of scrapie, and 32,580 at risk sheep in Great Britain between 1994 and 2003. Once again, genetic susceptibility was determined by laboratory testing of DNA for variants at codons 136, 154 and 171 of the prion gene.

The study had a case-control design and a suite of statistical tests including Cox proportional hazard regression was used for analysis. Hoinville et al. (2010) found a significantly $(\mathrm{p}<0.05)$ increased incidence of scrapie in the offspring of scrapie affected ewes but not rams after the effect of PrP genotype was controlled.
Epidemiological observations on pathways for scrapie transmission in sheep

Publications on the epidemiology of scrapie mention paternal transmission, maternal transmission, vertical transmission and horizontal or lateral transmission. These terms refer to transmission during either the prenatal, neonatal or postnatal periods in the life of sheep. The relationships among possible transmission pathways and their boundaries are shown diagrammatically in Fig. 2.

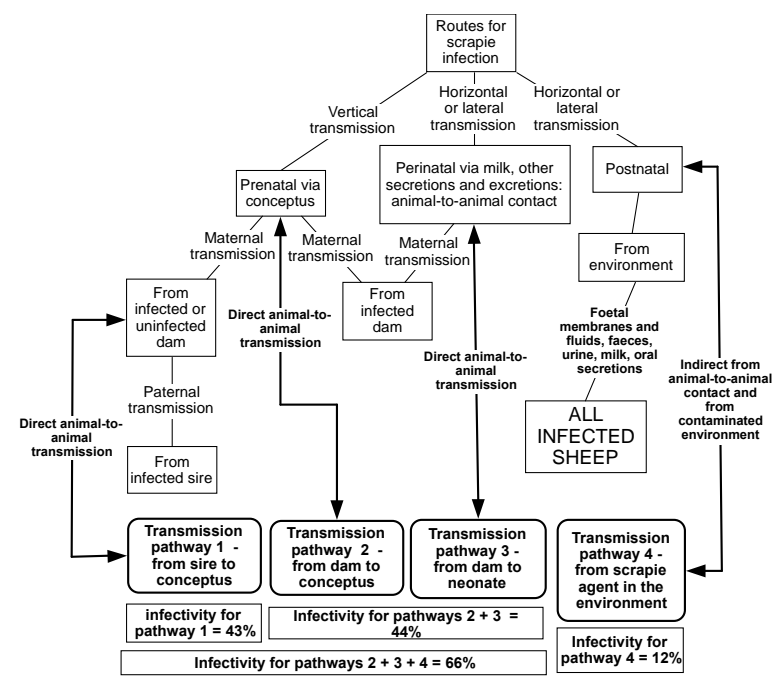

Fig. 2. Diagram showing relationships among possible transmission pathways for scrapie in the sheep and their connection the prenatal, neonatal and postnatal periods and the presence of the scrapie agent in sires, dams, the conceptus and the external environment.

Fig. 2 shows that the possible pathways for transmission of the scrapie agent are from parent to offspring directly or from non-parents, parents (that is, all members of a population) and fomites in the postnatal environment. Four transmission pathways are identified and these align with prenatal, neonatal (birth to weaning) and postnatal periods in the life of offspring and entail pathways from sire or dam to the conceptus (pathways 1 and 2), from dam to the neonate in the period from birth to weaning (pathway 3) and from all infected sheep postnatally (pathway 4). The prenatal period commences with oogenesis and terminates at parturition. All sheep will be exposed to the scrapie agent in the environment.

Populations 1-6 in Table 2 contain data from 2,060 offspring and 606 cases of scrapie that can be used to calculate infectivities (the proportion of exposures that result in infection) related to the four transmission pathways shown in Fig. 2. Lowest infectivity (12\%) occurred from pathway 4; that is, lateral transmission from the scrapie agent in the environment. 
Highest infectivity resulted when both sire and dam were scrapie infected. Infectivity from the paternal source (sire to conceptus, pathway1) was similar to that from the maternal source (pathways 2 and 3), implying that perinatal infection is overshadowed by infection occurring before birth.

\section{Direct observation in sheep of prenatal transmission of scrapie}

A single study in sheep has been identified where prenatal infection with the scrapie agent was demonstrated directly (Hourrigan et al., 1979). Lambs were removed from exposure to natural scrapie at birth and at 4, 9 or 20 months after birth and placed in isolation pens for long-term observation.

Six out of 54 sheep removed from exposure at birth succumbed to scrapie according to the diagnostic criteria employed. Twenty-three more deaths from scrapie occurred in sheep that were removed from exposure at different times during postnatal life. These 23 deaths represent the results of exposure to the scrapie agent during the prenatal period plus various lengths of exposure during postnatal life. According to linear regression analysis, the trend line and correlation are statistically significant $\left(\mathrm{y}=1.571 \mathrm{x}+11.042, \mathrm{R}^{2}=\right.$ $0.966, \mathrm{p}<0.0172$ ). Increasing periods of postnatal exposure acted additively to increase the burden of scrapie.

\section{Clinical observations on prenatal transmission of scrapie}

Couquet et al. (2005) report a pregnant ewe with suspected scrapie that was transferred to a veterinary diagnostic laboratory and gave birth to a ewe lamb 10 days later. The ewe was euthanased 16 days after the lamb was born and a post mortem diagnosis of scrapie was made by immunoblotting.

The lamb was separated from its mother as soon as it emerged from the birth canal, received no colostrum, was fed with milk replacers and was isolated to prevent horizontal transmission of scrapie. Six months later the lamb showed the first signs of scrapie and four months later it was euthanized when it could no longer stand. Scrapie was confirmed post mortem by immunoblotting and immunohistochemistry. This observation and that of Hourrigan et al. (1979) support the prenatal transmission of scrapie.

\section{Evidence from experimentation} Scrapie infectivity in sheep semen

Before 2012, the possibility that sheep semen could transmit scrapie was investigated by two approaches. One approach sought to transmit scrapie by parenteral administration of semen in lambs (Palmer, 1959), outbred mice (Hourrigan et al., 1979; Hadlow et al., 1982) or transgenic mice expressing the highest susceptibility variant of the ovine prion gene (Sarradin et al., 2008). The other approach applied methods such as immunohistochemistry or immunoblotting to identify the diseased form of the prion protein $\left(\mathrm{PrP}^{\mathrm{Sc}}\right)$ (Gatti et al., 2002).

Poor sensitivity of test methods can explain the failure of these early studies to detect scrapie infectivity in ovine semen. An additional consideration, namely statistical power, applies to the study by Sarradin et al. (2008). The study of Sarradin et al. (2008) sought to detect scrapie by means of intracerebral injections of semen from scrapie-affected Romanov rams into scrapie-susceptible transgenic mice overexpressing the high susceptibility allele of the sheep prion (PRNP) gene. None of the test mice developed scrapie, whereas control mice inoculated with preparations of brain from scrapie-affected sheep died from scrapie within 165 days. Three rams exposed to natural scrapie were used and provided single semen samples via an artificial vagina at one month, seven months or 13 months before death from scrapie. Sarradin et al. (2008) employed three experimental units in their overall study and single experimental units for three possible treatment levels that may correspond with the stage of scrapie disease. The power of the study is thus weak and provides weak evidence that scrapie does not transmit via germ plasm.

The most recent study on ovine semen (Rubenstein et al., 2012) demonstrated scrapie infectivity in two ways. One was by a transmission test with transgenic mice; that is by a test similar to that employed by Sarradin et al. (2008). The other involved a process for detecting the scrapie agent that comprised serial protein misfolding cyclic amplification (PMCA) followed by an immunoassay method (SOFIA).

The study by Rubenstein et al. (2012) merges clinical findings, history and laboratory testing into a coherent whole and is consistent with standard diagnostic methods. It was prompted by the discovery of scrapie in seven of 24 ewes in a 'sentinel' flock of that had been free of scrapie for 13 years. These sheep had been physically separated from scrapie-infected animals. The crucial point from the case history is that scrapieinfected rams had been used for breeding four months before scrapie was detected in the ewes.

The detection of scrapie infectivity on the semen of sheep by means of transmission studies with transgenic mice and protein misfolding cyclic amplification (PMCA) overturns earlier negative findings. Semen from scrapie-infected sheep is thus confirmed as a hazard for the transmission of scrapie.

Scrapie infectivity in the ovine and caprine conceptus Thirteen publications were found that demonstrate the scrapie agent in the conceptus of sheep and provide direct anatomical proof of prenatal transmission of scrapie in this species. Two publications provide similar findings for goats (O'Rourke et al., 2011; Schneider et al., 2015). Samples examined in these publications were obtained either post-partum or pre- 
partum at various times during gestation. The scrapie agent was detected by various methods including test transmissions in sheep, goats and mice, Western blot analysis, immunohistochemistry, enzyme linked immunosorbent assays (ELISA), protein multiplication cyclic amplification (PMCA), and bioassay in transgenic $\operatorname{tg} 388$ mice that overexpress the ovine prion gene

Nine of the publications sought for and found the scrapie agent in extra-embryonic tissues only (Pattison et al., 1972, 1974; Onodera et al., 1993; Race et al., 1998; Caplazi et al., 2004; Alverson et al., 2006; Lacroux et al., 2007; Santucciu et al., 2010). Three of the publications examined both extra-embryonic membranes and the foetus proper by means of Western blot analysis or immunohistochemistry and detected the scrapie agent in extra-embryonic membranes only (Tuo et al., 2001, 2002: Andreoletti et al., 2002).

Garza et al. (2011) and Spiropoulos et al. (2014) found the scrapie agent in both extra-embryonic tissues and the foetus proper by means of PMCA or bioassay in $\operatorname{tg} 388$ mice. These last two findings are consistent with an anatomical view of the conceptus as a whole organism, made up of the extra-embryonic membranes and foetus. Extra-embryonic membranes are external organs of the foetus and share the same circulatory system. The cells of foetus and extra-embryonic membranes have the same genotype.

Precedents from commonplace causes of abortion in ewes argue against a barrier in the conceptus that protects the ovine foetus from pathogens. The causative organisms of campylobacteriosis, listeriosis, toxoplasmosis and Border disease are found in both foetal membranes and the foetus (Broadbent, 1972; Hedstrom et al., 1987; Nettleton et al., 1998; Dubey, 2009).

Coetzer et al. (1994) list the protozoa, rickettsias, chlamydias, viruses, and bacteria capable of prenatal infection in sheep.

Prenatal infection with scrapie is thus conceivable at any time from oogenesis to parturition and the scrapie infection seen in the cotyledonary chorioallantois may be the result of transmission either before or after implantation. A high concentration of $\operatorname{PrP}^{\mathrm{Sc}}$ in the cotyledonary chorioallantois may reflect contiguity with maternal tissue and transplacental transmission. It may also indicate that the cotyledonary chorioallantois contains enough cellular prion protein $\left(\mathrm{PrP}^{\mathrm{c}}\right)$ for conversion to the disease form $\left(\mathrm{PrP}^{\mathrm{Sc}}\right.$ ) (Colby and Prusiner, 2013). In this connection, Tuo et al. (2001) found that the relative concentration of $\mathrm{PrP}^{\mathrm{c}}$ in the ovine cotyledonary chorioallantois was about four times and eight times that found in foetal bladder and kidney and similar to that found in foetal brain. Thumdee et al. (2007) report similar findings. Johnson et al. (2014) found that estrogen stimulation increases in $\mathrm{PrP}^{\mathrm{c}}$ expression in uteroplacental tissues, including the chorioallantois. In consequence, the high concentration of $\mathrm{PrP}^{\mathrm{Sc}}$ in the cotyledonary chorioallantois may simply reflect the relatively high tissue expression of $\operatorname{PrP}^{\mathrm{c}}$.

It is conceivable that the scrapie agent may arrive in the conceptus before implantation and infect oocytes or early embryos. Thumdee et al. (2007) found that the ovine prion gene is expressed in immature and mature ovine oocytes and ovine morulas. Similarly, Peralta et al. (2012) have identified relatively high expression of the mRNA that codes for PrP in bovine conceptuses at day 4 of gestation. These findings signify the very early availability of normal prion protein $\left(\mathrm{PrP}^{\mathrm{c}}\right)$ for conversion to the abnormal misfolded form $\left(\mathrm{PrP}^{\mathrm{Sc}}\right)$, a hallmark of prion disease (Prusiner, 1998). Prenatal infection with the scrapie agent as early as the oocyte stage is plausible.

To sum up, observations of the scrapie agent in foetal membranes and the foetus itself provide definitive anatomical evidence for the prenatal transmission of scrapie in both sheep and goats.

\section{Scrapie infectivity in washed or unwashed in vivo derived embryos}

Seven studies were identified that relate to the explicit question of whether scrapie can transmit in sheep by means of washed or unwashed in vivo derived embryos (Foster et al., 1992; Foote et al., 1993; Foster et al., 1996; Wang et al., 2001, 2002; Foster et al., 2006; Low et al., 2009; Foster et al., 2013). These are discussed in reverse chronological order. Table 3 shows results of analysis. The study of Foster et al. (2013) builds on an understanding of the importance of the prion protein gene (PRNP) and codons 136, 154 and 171 gene in genetic resistance to scrapie in sheep. In Cheviot sheep, PRNP genotypes of VRQ/VRQ and VRQ/ARQ are at risk from both local endemic scrapie and the SSBP/1 strain of the scrapie agent whereas the PRNP genotypes of VRQ/AHQ and VRQ/ARR are at risk only from the SSBP/1 strain. The clear-cut differences in the expression of disease that distinguish the SSBP/1 strain from the local endemic strain of scrapie were utilized in analysis.

Foster et al. (2013) studied Cheviot sheep at a site in Scotland and asked whether scrapie developed in embryo-derived offspring that were exposed to the SSBP/1 agent in surrogate dams and whether or not this exposure required genetic susceptibility in these dams. Accordingly, there were three exposure groups. The first group consisted of offspring derived from embryos that were gestated in ewes with a range of PRNP genotypes and which were not exposed to SSBP/1 scrapie ('infection controls' or 'unexposed group). The second group consisted of offspring derived from embryos that were gestated in ewes with scrapie resistant PRNP genotypes, which were challenged with SSBP/1. 
Table 3. Evidential value of studies on the transmission of scrapie in sheep by in vivo derived embryos.

\begin{tabular}{|c|c|c|}
\hline Studies by & Breed of sheep and source of scrapie agent & $\begin{array}{l}\text { Evidence for or against } \\
\text { transmission of scrapie by embryos }\end{array}$ \\
\hline Foster et al. (2103) & $\begin{array}{l}\text { Cheviot sheep with designed exposure to SSBP/1 strain } \\
\text { of scrapie and adventitious exposure to local endemic } \\
\text { strain of scrapie. }\end{array}$ & $\begin{array}{l}\text { Definitive for washed and unwashed } \\
\text { embryos }\end{array}$ \\
\hline Low et al. (2009) & $\begin{array}{l}\text { Embryos from sheep with natural scrapie gestated in } \\
\text { scrapie free Suffolk ewes from New Zealand. }\end{array}$ & Weak against washed embryos \\
\hline Foster et al. (2006) & $\begin{array}{l}\text { Cheviot sheep but embryo donors had no exposure to } \\
\text { scrapie. }\end{array}$ & Ruled out as evidence \\
\hline Wang et al. $(2001,2002)$ & Suffolk sheep with a high incidence of natural scrapie. & Ruled out as evidence (see text) \\
\hline Foster et al. (1996) & $\begin{array}{l}\text { Cheviot sheep with designed exposure to SSBP } / 1 \text { strain. } \\
\text { Adventitious exposure to local endemic strain of scrapie } \\
\text { via semen from infected rams. }\end{array}$ & $\begin{array}{l}\text { Definitive for washed and unwashed } \\
\text { embryos }\end{array}$ \\
\hline Foote et al. (1993) & $\begin{array}{l}\text { Suffolk sheep infected with third to fourth passage strain } \\
\text { of Suffolk scrapie agent. Cheviot sheep with SSBP/1 } \\
\text { strain of scrapie. }\end{array}$ & Ruled out as evidence \\
\hline $\begin{array}{l}\text { Foster } \text { et al. } \text { (1992); } \\
\text { additional data from EFSA } \\
\text { (2010) }\end{array}$ & Cheviot sheep. SSBP/1 strain. & Strong for unwashed embryos. \\
\hline
\end{tabular}

This exposure group can demonstrate prenatal transfer or of SSBP/1 scrapie from ewes with PRNP genotypes coding for scrapie resistance. The third group consisted of offspring derived from embryos that were gestated in ewes with scrapie susceptible PRNP genotypes, which were challenged with SSBP/1. This exposure group can demonstrate or not prenatal transfer of SSBP/1 scrapie from ewes with PRNP genotypes coding for scrapie susceptibility.

Embryos came from a panel of 15 donors with PRNP genotypes encoding for at least one VRQ allele and which were inseminated by semen from three rams, one of which had the PRNP genotype of VRQ/ARQ and the other two had the PRNP genotype of VRQ/ARR. Some embryos were washed according to IETS recommendations and others were not. Three of the embryo donors developed endemic scrapie after embryo collection. The remaining embryo donors and the three rams died with illnesses other than endemic scrapie in its expected form.

Sixteen cases of scrapie attributable to either the SSBP/1 or the endemic strain of scrapie were diagnosed in the 59 sheep that originated from transferred embryos. The distribution of these cases within exposure groups and according to PRNP genotypes permits three significant conclusions. First, embryo washing according to the recommendations of the IETS did not protect lambs from scrapie and can be regarded as an ineffective secondary protective measure. Second, prenatal transmission of scrapie occurs in sheep and is possible when dams have PRNP genotypes that code for susceptibility to scrapie. The observation that SSBP/1 scrapie transmitted from susceptible but not resistant dams inoculated with SSBP/1 scrapie indicates that genetically resistant dams provide an effective barrier against prenatal transmission. Third, scrapie is transmissible by in vivo derived embryos in sheep. Conclusion 2 of the hypothesis-testing protocol applies to the study of Foster et al. (2013): Scrapie transmits in sheep by means of unwashed or washed in vitro derived embryos and it is concluded correctly that it does so.

Low et al. (2009) report a correlative experiment in which embryos transferred from naturally infected ewes were used to investigate whether in vivo derived embryos can carry the agent of classic scrapie. The study was conducted on quarantined premises with Suffolk sheep that were homozygous for the ARQ allele of the PRNP gene.

In Suffolks, ARQ/ARQ homozygotes and ARQ/ARH heterozygotes have the greatest susceptibility to natural scrapie infection (Baylis et al., 2004). Thirty-nine experimental lambs were produced from embryos out of naturally infected donor ewes. Since the use of natural scrapie necessitated null treatment controls, 17 unexposed lambs were produced from embryos collected from New Zealand-derived Suffolk ewes. Twenty-eight sheep derived from scrapie-exposed embryos survived to an end point of five years of age and 12 of the 17 sheep derived from unexposed embryos survived to the same endpoint.

No histopathological or immunohistochemical evidence of scrapie was found at post mortem in any of the embryo-derived sheep. From this, Low et al. (2009) concluded that their study provided no evidence for transmission of scrapie and reinforced published evidence that vertical transmission of scrapie may be circumvented by embryo transfer procedures. Estimates of statistical power provided by Low et al. (2009) set the likelihood of scrapie transmission by in 
vivo derived embryos as high as one in 11 or $9.1 \%$, with 95\% confidence limits.

The method for estimating statistical power is not described and it is unclear whether calculations are based on 28 embryo-derived sheep or eight scrapie affected ewes that donated embryos. Calculations on embryo-derived offspring would be confounded by pseudoreplication (Ruxton and Colgrave, 2006). Embryos are dependent variables and units for measurement whereas ewes donating embryos are the independent variables and units for experiment. The stated $9.1 \%$ risk cannot be determined from eight experimental units. The results of Low et al. (2009) thus provide weak evidence against the transmission of scrapie in sheep by means of washed in vitro derived embryos.

Foster et al. (2006) describe a project that employed embryo transfer to generate scrapie-free flocks of sheep containing individuals with PrP genotypes known to confer high susceptibility. The findings are crucially significant for understanding the aetiology of scrapie. They confirm that scrapie disease has two necessary causes: susceptibility of hosts and the presence of the scrapie agent. However, none of the semen donors, embryo donors or embryo recipients in the study of Foster et al. (2006) exhibited scrapie. As a consequence, there was no testable exposure to the scrapie agent that could be linked to embryos. In short, the scrapie agent did not transmit via in vivo derived embryos because it was absent from the donors of germ plasm in the first place and the study is not relevant to the explicit question of this review.

The study by Wang et al. (2001) was a correlative experiment to investigate the potential for scrapie to transmit by embryo transfer in flocks where the disease is endemic. A supplementary paper (Wang et al., 2002) provided information on the scrapie-resistance genotypes of the sheep that were used. The experiment consisted of obtaining embryos from donor ewes out of six different scrapie-infected flocks of Suffolk sheep, transferring these embryos to scrapie-free recipients and monitoring the occurrence of scrapie in embryoderived offspring, embryo donors and embryo recipients. Embryos from 38 donor ewes were transferred to 58 recipients and resulted in 94 viable lambs, which were monitored until they were 60 months old.

Scrapie according to an unstated definition was not observed in the response units (the offspring). However, the study of Wang et al. (2001, 2002) has insufficient power for accepting its stated hypothesis that 'the transmission of scrapie may be circumvented by embryo transfer'. The timing of embryo collection in relation to the stage of scrapie infection is not described and an important dimension in scrapie exposure is unknown. The mortality rate of embryo- derived sheep in the first year of life was an exceptional $21.3 \%$. Causes of death are not reported and mortalities could have assorted differentially according to the scrapie status of embryo donors. Deaths before 12 months of age could well have been due to scrapie. Scrapie can be exhibited in lambs as young as six months (Brotherston et al., 1968; Couquet et al., 2005). Other issues that affect the evidential value of the study by Wang et al. $(2001,2002)$ regarding the transmission of scrapie in sheep by in vivo derived embryos are detailed in the online supporting material.

Foster et al. (1996) investigated the progeny of embryos with genotypes that were homozygous or heterozygous for scrapie susceptibility, which were obtained from scrapie-susceptible or scrapie-resistant ewes injected or not with the SSBP/1 strain of the scrapie agent 246 days before embryos were harvested and which were washed or not according the protocols of the IETS. Donor ewes were inseminated with semen from two homozygous scrapie-susceptible rams to ensure that both homozygous and heterozygoussusceptible lambs were in the treatment groups. Scrapie disease, referable to the field strain, was diagnosed in these two rams at 236 and 287 days after semen collection:

Scrapie, referable to the field strain and not the SSBP/1 strain, appeared in homozygous and heterozygoussusceptible lambs derived from donor ewes that were exposed or not to the SSBP/1 strain of scrapie and from ova that were washed or not according to the IETS protocol. Scrapie disease did not appear in the heterozygous susceptible lambs derived from scrapie resistant ewes. Abductive reasoning (inference to the best explanation) attributes the appearance of scrapie in the treatment groups of Foster et al. (1996) to transmission of the scrapie agent from infected semen to embryos. The washing of embryos according to IETS requirements did not prevent transmission.

Foster et al. (1996) were hesitant in incriminating the scrapie-infected rams as the source of scrapie seen in their treatment groups: the argument being the absence of sound case for scrapie infectivity in semen at that time. Scrapie infectivity in ram semen has now been demonstrated (Rubenstein et al., 2012). The results of Foster et al. (1996) can thus be attributed to the transmission of scrapie by semen. The infection pathway from ram to embryo donor and thence to embryo recipients entails transmission by embryos. As a consequence, the results of Foster et al. (1996) show the transmission of scrapie by in vivo derived embryos treated according to the requirements of the IETS.

Foote et al. (1993) describe two experiments on the transmission of scrapie by in vivo derived embryos. The first experiment was conducted at a site in Texas and involved Suffolk sheep, a Suffolk-passaged strain of scrapie and four treatments: (1) embryos from scrapie- 
infected donor ewes were gestated in scrapie-free recipients ('via embryo'); (2) embryos from scrapie free donors were gestated in scrapie-infected recipients ('via uterus'); (3) embryos derived from scrapie-free donors were gestated in scrapie-free recipients ('negative controls'); and, (4) embryos derived from scrapie-infected ewes were gestated in scrapie-infected recipients ('positive controls'). The second experiment was conducted at a site in Utah and involved Cheviot sheep, the SSBP/1 strain of scrapie and two treatments: (1) embryos from scrapie-infected donor ewes were gestated in scrapie-free recipients and (2) embryos derived from scrapie-infected ewes were gestated in scrapie-infected recipients ('positive controls').

The proposition examined by Foote et al. (1993) was that the appearance of their conception of scrapie demonstrates scrapie transmission or not by means of in vivo derived embryos. No such scrapie was observed. However, the large and unexplained mortalities observed in the study merit examination. In particular, mortality to 23 months of age was distributed disproportionately among the four treatment groups and may point to an unexpected consequence of exposure to the scrapie agent.

When data from the two experiments are pooled mortalities rates were $32 \%$ for the 'via embryo' group, $52 \%$ for the 'via uterus' group, $45 \%$ for the group exposed both 'via embryo' and 'via uterus' and $23 \%$ for the scrapie unexposed group. These percentages are significantly different $(\mathrm{P}<0.0158$ by Pearson Chisquare) and indicate an impact of prenatal exposure to the scrapie agent. Mortalities calculated from numbers of Suffolk offspring alive at 24 months and 60 months were $24.4 \%$ for the 'via embryo' group and $6.1 \%$ for the negative controls $(\mathrm{P}<0.031)$. These results indicate an impact of the scrapie agent on unwashed in vivo derived embryos in sheep and deserve further consideration. The study of Foote et al. (1993) is ruled out as evidence on whether scrapie transmits via preimplantation embryos.

The earliest study of scrapie infectivity in in vivo derived embryos (Foster et al., 1992; EFSA, 2010) involved Cheviot sheep and the SSBP/1 strain of scrapie at the National Pathogenesis Unit in Edinburgh. It investigated whether scrapie can be transferred early in gestation or in the ovary and it used embryos from scrapie-infected ewes as the experimental manipulation. Genetic susceptibility to scrapie was determined according to information on the Sip (scrapie incubation period) and prion protein genotype and was obtained from pedigrees and restriction fragment length analysis (RFLP). Subsequent analysis of the Sip genotype identified three dominant codons in the ovine prion gene $(136,154$ and 171) that control susceptibility to scrapie (Hunter et al., 1996). Six donor ewes were injected subcutaneously with an extract from brains of sheep containing the SSBP/1 isolate of the scrapie agent six months before hormonally induced superovulation, intrauterine insemination and the collection of embryos. Scrapie appeared at 40, 70, 82 and 95 days after embryo collection in the homozygous susceptible donors and at 146 and 180 days in the heterozygous susceptible donors. The single ram used as a semen donor was heterozygous for the susceptibility gene. The ram was subsequently injected with the SSBP/1 isolate of the scrapie agent and showed signs of scrapie 309 days later. Sixteen ewes homozygous for scrapie resistance were used as surrogate dams for 37 embryos and gave birth to 26 lambs. Lambing occurred indoors in premises disinfected with a $20 \%$ sodium hypochlorite solution. Lambs were weaned at four months of age, were strictly isolated from other sheep and were grazed on pasture that had never been exposed to scrapie-infected or parturient sheep. The success rate of embryo transfer was 26 lambs from 37 embryos or $70 \%$. Six of the 26 embryo-derived lambs died within the first year of life and as a result of 'diseases unrelated to scrapie'. All six homozygous susceptibles developed scrapie. Two of the 11 heterozygotes developed scrapie and a further six were put down because of what was stated to be metabolic illness (EFSA, 2010). Two of these six sheep with metabolic illness were scrapie-positive according to immunoblots. In other words, four of the 11 heterozygotes were diagnosed with scrapie and another four died from 'metabolic illness' during the period of experimental observations. None of the three homozygous resistant sheep died during the period of experimental observations.

In summary, of the 26 sheep derived from 37 transferred embryos, 10 or $38 \%$ died from scrapie. A further 10 or $38 \%$ of the 26 embryo-derived sheep died from other diseases, including four from 'metabolic illness'. Six of these died before the age of 12 months. The total mortality to about three years of age was 20 out of 26 sheep or $77 \%$. Deaths from causes other than classically expressed scrapie arouse interest given that scrapie infection was the experimental treatment. A thought experiment can be used to calculate a prior probability for testing significance. The question is how many cases of scrapie could be expected in 20 identical sheep in identical circumstances except for exposure to SBPP/1 scrapie in embryo donors. An incidence of up to four cases allows for statistical significance by the Pearson Chi-square test. The incidence of scrapie recorded by Foster et al. (1992) far exceeds an estimate of prior probability. Scrapie due to the endemic strain in the Cheviot flock at the National Pathogenesis Unit had a maximum annual incidence of $1 \%$ and a maximum incidence of $5.4 \%$ in birth cohorts recorded (Redman et al., 2002). Accordingly, the study of Foster et al. (1992) is judged as strong evidence that scrapie 
transmits prenatally in sheep (see online supporting material).

\section{Evidence from causal reasoning}

A set of pathophysiological observations line up to prevent rejection and allow acceptance of prenatal transmission of scrapie in sheep. These observations constitute the case around causal reasoning derived from knowledge of scrapie in sheep and goats. They relate to preconditions for prenatal transmission that affirm biological plausibility, an important criterion of causation (Hill, 1977). Key preconditions are: (1) The scrapie agent is able to disperse throughout the body and to the reproductive organs. (2) Exposure to the scrapie agent is possible at any point during the prenatal period from oogenesis to the zygote/blastocyst, embryogenesis and foetal stages. (3) The conceptus is susceptible to infection with the scrapie agent. The pertinent pathophysiological observations occur in sequence starting from the fact that scrapie is a contagious disease and can be spread from animal to animal by direct or indirect contact (Greig, 1940; Gordon, 1957; Dickinson et al., 1965; Brotherston et al., 1968; Hourrigan et al., 1979; Hoinville, 1996; Detwiler and Baylis, 2003; Ryder et al., 2004; Foster et al., 2006; Gough et al., 2015; Hawkins et al., 2015). The property of contagiousness requires that the scrapie agent operate portals of exit from infected animals and portals of entry into uninfected animals and has capacity to pass the usual barriers against infection. Demonstrated portals of exit for the scrapie agent in sheep include excretions and ejecta (faeces, urine and foetal membranes) and secretions (milk, oral secretions and semen) (Table 4). These various portals of exit demonstrate that the scrapie agent is able to traverse biological membranes and disperses through the body. The presence of the scrapie agent in foetal membranes shows that the scrapie agent can pass across cell and tissue barriers within the reproductive tract of sheep. As to dispersal of the scrapie agent through the body, the presence of the scrapie agent in blood, prionaemia, carries the same consequences for the pathogenesis of scrapie as those applying to viraemia and bacteraemia in viral and bacterial diseases. Prionaemia signifies (1) that the scrapie agent can be distributed throughout the body, including the reproductive tract and (2) that mechanisms exist for passage of the scrapie agent across the endothelial cell sheet and into interstitial fluid and the lymphatic system, where the known functions of the lymphoreticular system in the pathogenesis of scrapie (Jeffrey and González, 2007; van Keulen et al., 2008) can come into play. Haematogenous carriage was reported for scrapie in sheep in 2002 and has been corroborated repeatedly with different detection methods. Hunter et al. (2002) showed that transfusions of blood from BSE or scrapieinfected sheep transmitted these two diseases to uninfected sheep. Thorne and Terry (2008) demonstrated the presence of the scrapie agent in the blood of scrapie-infected sheep by means of PMCA. Houston et al. (2008) corroborated earlier findings of the research group (Hunter et al., 2002) and showed transmission rates by blood transfusion of $36 \%$ for BSE and $43 \%$ for scrapie. Terry et al. (2009) found $\mathrm{PrP}^{\mathrm{Sc}}$ in cells isolated from the blood of $55 \%$ of sheep infected with scrapie and $71 \%$ of sheep infected with BSE. PrPSc was found in blood cells several months before the onset of clinical signs in scrapie-infected sheep. Rubenstein et al. (2010) used PMCA and found the disease-associated form of the prion protein $\left(\mathrm{PrP}^{\mathrm{Sc}}\right)$ in blood plasma from sheep at both the preclinical and clinical stages of scrapie. Edwards et al. (2010) used immunoassays to investigate the nature of the blood cells of scrapie-infected sheep that carried $\mathrm{PrP}^{\mathrm{Sc}}$, the surrogate marker for prion disease. The mononuclear cells in blood carrying $\mathrm{PrP}^{\mathrm{Sc}}$ during the preclinical and clinical stages of scrapie had a cell surface phenotype that defined them as a subpopulation of B lymphocytes. Dassanayake et al. (2011) used similar methods to associate the scrapie agent in the blood of sheep with a sub-population of B lymphocytes and also with platelet rich plasma. Subsequently, Dassanayake et al. (2012) identified the scrapie agent in both $B$ and $T$ lymphocytes in the blood of scrapie-infected sheep and the blood of scrapie-infected goats. Other demonstrations of the scrapie agent in the blood of sheep come from Bannach et al. (2012), Andreoletti et al. (2012) and Lacroux et al. (2012). Bannach et al. (2012) employed a method for based on surface-FIDA (fluorescence intensity distribution analysis) and showed that disease-specific aggregates of prion protein could be detected in the blood plasma of scrapie-infected sheep. Andreoletti et al. (2012) used bioassays in genetically susceptible sheep and transgenic mice overexpressing the ovine prion gene for scrapie susceptibility to investigate scrapie transmission by blood. They showed that the efficacy for transmitting the PG127 strain of scrapie depended more on the viability of transfused white blood cells than upon the degree of infectivity that was measured by intracerebral inoculation in transgenic mice. As a consequence, bioassays that use non-living material, including highly sensitive versions with transgenic mice, are inherently limited as to the information they can provide on infectivity of the scrapie agent. The scrapie agent can be found in the lymphoreticular system of both sheep (van Keulen et al., 1996; Schreuder et al., 1998; Andreoletti et al., 2000; O'Rourke et al., 2000, 2002; Press et al., 2004; Gonzalez et al., 2008; Dennis et al., 2009; Ryder et al., 2009; Jeffrey et al., 2011; Toppets et al., 2011), and goats (Monleon et al., 2001; Gonzalez et al., 2009, 2010). 
Table 4. Evidence for scrapie infectivity in tissues and excretions of sheep and goats.

\begin{tabular}{|c|c|c|}
\hline Tissue & References & Methods of detection \\
\hline Faeces, gut, liver & Sheep: Everest et al. (2011); Terry et al. (2011). & sPMCA, IHC, immunoblotting \\
\hline Urine and kidneys & Sheep: Ligios et al. (2007); Rubenstein et al. (2012). & \\
\hline $\begin{array}{l}\text { Foetal membranes and } \\
\text { fluids }\end{array}$ & $\begin{array}{l}\text { Sheep: Pattison et al. }(1972,1974) ; \text { Onodera } \text { et al. (1993); } \\
\text { Race } \text { et al. (1998); Tuo et al. }(2001,2002) ; \text { Andreoletti } \text { et al. } \\
\text { (2002); Alverson } \text { et al. }(2006) ; \text { Lacroux } \text { et al. }(2007) \text {. } \\
\text { Goats: O'Rourke } \text { et al. }(2011) ; \text { Schneider } \text { et al. }(2015) \text {. }\end{array}$ & $\begin{array}{l}\text { sPMCA, IHC, transmission to } \\
\text { tg388 mice, SAF detection, } \\
\text { immunoblotting, transmission to } \\
\text { sheep }\end{array}$ \\
\hline Lochia & Not examined & \\
\hline \multicolumn{3}{|l|}{ Secretions } \\
\hline Milk & $\begin{array}{l}\text { Sheep: Konold et al. (2008); Lacroux et al. (2008); Maddison } \\
\text { et al. (2009); Ligios } \text { et al. (2011); Konold } \text { et al. (2013a). } \\
\text { Goats: Konold } \text { et al. (2013b). }\end{array}$ & $\begin{array}{l}\text { sPMCA, IHC, transmission to } \\
\operatorname{tg} 388 \text { mice }\end{array}$ \\
\hline $\begin{array}{l}\text { Oral secretions and } \\
\text { salivary glands }\end{array}$ & $\begin{array}{l}\text { Sheep: Vascellari et al. (2007); Maddison et al. (2010); Gough } \\
\text { et al. (2012). }\end{array}$ & sPMCA; IHC \\
\hline Semen & Sheep: Rubenstein et al. (2012). & $\begin{array}{l}\text { sPMCA, transmission to } \operatorname{tg} 388 \\
\text { mice }\end{array}$ \\
\hline
\end{tabular}

In both sheep and goats, the scrapie agent is present in cells of the lymphocyte lineage ( $\mathrm{T}$ cell and $\mathrm{B}$ cells) and the mononuclear phagocyte lineage (macrophages and dendritic cells) and in discrete and diffuse lymphoid organs where it is used to diagnose scrapie during the preclinical stage of infection. These observations indicate correspondence between the pathogenesis of scrapie in sheep and goats and imply a similar status for their germplasm as hazards for scrapie.

The general migratory and circulatory activities of lymphocytes and mononuclear phagocytes, which allow concerted function of the lymphoreticular and immune systems and immunosurveillance, are known to operate in the female and male reproductive tracts of sheep and goats. Transit of $\mathrm{PrP}^{\mathrm{Sc}}$-bearing lymphocytes and mononuclear phagocytes through reproductive tissues and organs will enable exposure of germplasm to the scrapie agent. In this connection, Smith et al. (1970) investigated the nature of the cells present in afferent or peripheral lymph draining the ovary and uterus of six sheep. They recorded a cell concentration of 200-700 cells per $\mu \mathrm{l}$ in lymph from a lymphatic in the mesovarium and in the drainage field of the ovary. The cell population was comprised of comprising 9095\% lymphocytes and 5-10\% mononuclear phagocytes. Staples et al. (1982) used dyes to identify lymphatics within the mesometrium and along the utero-ovarian pedicle in sheep and goats. Lymph from these lymphatics in both sheep and goats contained up to 200 cells per $\mu \mathrm{l}$ and consisted of more than $94 \%$ lymphocytes and less than $6 \%$ mononuclear phagocytes.

Alders and Shelton (1990) extended findings about cells in ovarian uterine by looking at subsets according to some cluster of differentiation (CD) surface markers.
A relatively higher proportion of $\mathrm{T}$ cells occurred in utero-ovarian lymph (approx. 80\% CD5+, 50\% CD4+ and $23 \% \mathrm{CD} 8+$ ) compared with peripheral blood (approx. 55\% CD5+, 18\% CD4+ and 12\% CD8+). A relatively lower proportion of B cells occurred in lymph (approx. 10\%) compared to blood (approx. 30\%). Smith et al. (1970) also investigated cells in peripheral lymph draining from the testis of five sheep. They found a cell concentration of 100-300 cells per $\mu$ l that was composed of 75-82\% lymphocytes, 5-20\% mononuclear phagocytes and $0-8 \%$ other cells (polymorphonuclear neutrophils, eosinophils, large basophilic cells and cells of the plasma cell series). In other words, cells able to carry the scrapie agent transit through testicular tissue in the sheep.

Knowledge of the cellular content in peripheral lymph draining from the female reproductive tract of both sheep and goats attests to a pathway for entry of the scrapie agent into the ovarian/oviductal/uterine environment. Cells with a known potential for carrying the scrapie agent migrate through tissues of the female reproductive tract of the two species. In sheep, at least, the same considerations about exposure to the scrapie agent apply in the male reproductive tract.

Immune responses in early pregnancy in the sheep involve traffic to the reproductive tissues of lymphoid cells known to carry the scrapie agent: for example, CD68 positive dendritic cells (Scott et al., 2006, 2009). CD68 detects the molecule macrosialin and is useful for identifying cells of the mononuclear phagocyte system (Janeway et al., 2001; Galli et al., 2011), which functions in the antigen-presentation step of the immune response (Paul, 2013).

The CD68 marker stimulates additional interest because it has been employed in studies of the 
pathogenesis of scrapie in sheep and because studies in mice assign a role to dendritic cells (CD68-positive) in spreading the scrapie agent within the body (Beringue et al., 2000; Huang et al., 2002).

Andreoletti et al. (2002) identified CD68 positive cells in the endometrium of ewes with scrapie-infected placentas but it was unclear whether the misfolded prion protein in these cells implicated a scrapie transmission pathway from the dam to the foetus, the foetus to the dam or transmission in both directions. Åkesson et al. (2011) highlighted the participation of CD68 bearing cells in the transit of experimentally introduced prion protein from the gut of lambs. They undertook a study where recombinant ovine prion protein $(\mathrm{rPrP})$ was inoculated into gut loops of young lambs and its transportation across the intestinal wall was tracked. This inoculated $\mathrm{rPrP}$ was associated with macrophages expressing the CD68 molecule. Accordingly, adjustments to the maternal immune system during pregnancy that allow for the presence of non-self or foreign tissue, the conceptus, in the uterine tubes and uterus (Robertson, 2000; Ott and Gifford, 2010) can open pathways for transmission of the scrapie agent.

Passage of the scrapie agent across biological membranes will involve the processes of endocytosis, exocytosis and transcytosis by which macromolecules and particles are taken into cells, expelled from cells and transported across cellular sheets (Alberts et al., 2002). These processes apply to prions (including the scrapie agent) because prions are proteins (Colby and Prusiner, 2013).

Exosomes are essential to endocytosis, exocytosis and transcytosis. Exosomes are small membranous vesicles that are secreted by cells of various sorts and found in body fluids such as urine and plasma and cell culture media. Exosomes may function in communication between cells, removing unwanted protein from cells and transferring pathogens, such as prions, and toxic proteins, such as the amyloid precursor protein involved in Alzheimer's disease, between cells (Bellingham et al., 2012).

Transport of scrapie prions by means of exosomes was suggested by observations that supernatants from longterm cells cultures of scrapie-infected ovine brain transmitted scrapie by intracerebral inoculation of mice (Gustafson and Kanitz, 1966).

Jeffrey et al. (2009) found that accumulations of $\operatorname{PrP}^{\mathrm{Sc}}$ at the ultrastructural level corresponded with abnormal endocytosis, increased endo-lysosomes, microfolding of plasma membranes and was associated with the release and transfer of $\mathrm{PrP}^{\mathrm{Sc}}$ among neurons and glial cells. McGovern and Jeffrey (2013) investigated abnormal prion protein in chromaffin cells of the adrenal gland of sheep infected with scrapie and showed that accumulations of $\operatorname{PrP}^{\mathrm{Sc}}$ was associated with changes in cell membranes. They suggested that $\mathrm{PrP}^{\mathrm{Sc}}$ released from chromaffin cells in exosomes was a source of the scrapie agent in blood. Finally, Åkesson et al. (2011) found prominent transcytotic activity and exosome release from the follicle associates epithelium of ileal Peyer's patches but this could not be associated with transportation of $\mathrm{PrP}^{\mathrm{Sc}}$ across the mucosal barrier. In short, exosomes and the processes of endocytosis and exocytosis provide a means by which the scrapie agent can enter cells and depart from cells. The known portals of entry and exit for the scrapie are thus explainable at the cellular and sub-cellular level of biological organisation. Furthermore, the transmission of scrapie by means of exosomes demonstrates that cells do not have to be in direct contact to allow transfer of the scrapie agent. Relevance for prenatal transmission is that the scrapie agent can transmit at any site in the reproductive tract.

\section{Extension of findings to goats}

Correspondence between key aspects of pathophysiology of scrapie in sheep and goats argues for prenatal transmission in both species and by extension is extremely strong presumptive evidence that semen and unwashed embryos from goats are hazards for the transmission of scrapie.

(1) The scrapie agent is found in the conceptus of infected goats (O'Rourke et al., 2011; Schneider et al., 2015) and infected sheep (Race, 1998; Tuo et al, 2001, 2002: Andreoletti et al., 2002; Alverson et al., 2006; Lacroux et al., 2007).

(2) The scrapie agent occurs in the blood of infected sheep (Hunter et al., 2002; Houston et al., 2008; Thorne and Terry, 2008; Edwards et al., 2010; Rubenstein et al., 2010; Andreoletti et al., 2012; Bannach et al., 2012; Lacroux et al ., 2012) and in the blood of infected goats (Dassanayake et al., 2011, 2012).

(3) The milk of infected sheep and infected goats (Konold et al., 2013a, 2013b) can carry the scrapie agent.

(4) The lymphoreticular system of infected sheep (van Keulen et al., 1996; Schreuder et al., 1998; Andreoletti et al., 2000; O'Rourke et al., 2000, 2002; Gonzalez et al., 2008; Dennis et al., 2009; Ryder et al., 2009; Toppets et al., 2011), and infected goats (Gonzalez et al., 2009, 2010; Monleon et al., 2011). In both sheep and goats, the scrapie agent is present in cells of the lymphocyte lineage ( $\mathrm{T}$ cell and $\mathrm{B}$ cells) and the mononuclear phagocyte lineage (macrophages and dendritic cells) and in discrete and diffuse lymphoid organs, where it is used to diagnose scrapie during the preclinical stage of infection.

\section{Concluding remarks}

Evidence from each of three sources (epidemiological and clinical observation, experiment and causal reasoning) demonstrates that scrapie transmits prenatally in sheep and goats. Their convergence 
allows a firm decision. One line of evidence, causal reasoning, was useful for detecting unstated and untenable premises and is suggested more deliberate use biosecurity. For example, it raised the possibility that prenatal transmission of scrapie in sheep formed a possible basis for action from the time that scrapie infectivity was identified in foetal membranes (Pattison et al., 1972). The definitive argument comes from anatomy and precludes uncertainty.

Prenatal transmission characterises semen and in vivo derived embryos as presumptive hazards for the transmission of scrapie in sheep and goats, bearing in mind the OIE's definition of a hazard: 'a biological, chemical or physical agent in, or a condition of, an animal or animal product with the potential to cause an adverse health effect' (OIE, 2015). The second line of evidence, experimentation, confirms that semen (Rubenstein et al., 2012) and in vivo derived embryos from sheep are hazards for the transmission of scrapie. Two studies (Foster et al., 1996; Foster et al., 2013) confirm that in vivo derived embryos from scrapie infected sheep, whether washed or unwashed according to the recommendations of the International Embryo Transfer Society (2010), can transmit scrapie. Studies of Foote et al. (1993) and Foster et al. (1992) point to transmission of scrapie by unwashed in vivo derived embryos from scrapie infected sheep transmit scrapie. The study of Low et al. (2009) provides weak evidence that washed in vivo derived embryos from scrapie infected sheep do not transmit scrapie.

Causal reasoning, the third line of evidence pursued in the systematic review, shows that conclusions from epidemiology and experimentation are biologically plausible, an important criterion of causation (Hill, 1977). Key pathophysiological preconditions for scrapie transmission by semen and in vivo derived embryos operate in the sheep and goat. The scrapie agent is able to disperse throughout the body and to the reproductive organs. Carriage of the scrapie agent by lymphocytes and mononuclear phagocytes combine with the phenomenon of lymphocyte recirculation to allow exposure to the scrapie agent throughout the male and female reproductive systems. There are no privileged sites. Exposure to the scrapie agent is possible at any point during the prenatal period from spermatogenesis or oogenesis to the zygote/blastocyst, embryogenesis and foetal stages. Exosomes containing the scrapie agent occur in tissue fluids and can expedite transmission. The cellular prion protein is expressed in immature and mature ovine oocytes and this marks the onset of susceptibility to scrapie infection. Causal reasoning provides definitive evidence that scrapie transmits prenatally in goats and extremely strong presumptive evidence that semen and unwashed embryos from goats are hazards for the transmission of scrapie.

\section{References}

Agricultural Research Service, US Department of Agriculture. 1966. Report of Scrapie Seminar Held At Washington, D.C., January 27-30, 1964. Agricultural Research Service, US Department of Agriculture.

Åkesson, C.P., McGovern, G., Dagleish, M.P., Espenes, A., Press, C. McL., Landsverk, T. and Jeffrey, M. 2011. Exosome-producing follicle associated epithelium is not involved in uptake of PrPd from the gut of sheep (Ovis aries): an ultrastructural study. PLoS One. 6, e22180.

Alberts, B., Johnson, A., Lewis, J., Raff, M., Roberts, K. and Walter, P. 2002. Molecular Biology of the Cell, $4^{\text {th }}$ Ed. Garland Science, New York.

Alders, R.G. and Shelton, J.N. 1990. Lymphocyte subpopulations in lymph and blood draining from the uterus and ovary in sheep. Reprod. Fertil. Dev. 17, 27-40.

Alverson, J., O’Rourke, K.I. and Baszler, T.V. 2006. $\mathrm{PrP}^{\mathrm{Sc}}$ accumulation in fetal cotyledons of scrapieresistant lambs is influenced by fetus location in the uterus. J. Gen. Virol. 87, 1035-1041.

Andreoletti, O., Berthon, P., Marc, D., Sarradin, P., Grosclaude, J., van Keulen, L., Schelcher, F., Elsen, J.M. and Lantier F. 2000. Early accumulation of $\mathrm{PrP}^{\mathrm{Sc}}$ in gut-associated lymphoid and nervous tissues of susceptible sheep from a Romanov flock with natural scrapie. J. Gen. Virol. 81, 3115-3126.

Andreoletti, O., Lacroux, C., Chabert, A., Monnereau, L., Tabouret, G., Lantier, F., Berthon, P., Eychenne, F., Lafond-Benestad, S., Elsen, J.M. and Schelcher, F. 2002. $\operatorname{PrP}^{\mathrm{Sc}}$ accumulation in placentas of ewes exposed to natural scrapie: influence of foetal PrP genotype and effect on ewe-to-lamb transmission. J. Gen. Virol. 83, 2607-2616.

Andreoletti, O., Litaise, C., Simmons, H., Corbiere, F., Lugan, S., Costes, P., Schelcher, F., Vilette, D., Grassi, J. and Lacroux, C. 2012. Highly efficient prion transmission by blood transfusion. PLoS Pathogens. 8, e 002782.

Animal Health Australia. 2009. Australian Veterinary Emergency Plan. Ausvetplan Disease Strategy, Scrapie, Version 3.0, 2009. Anonymous. https://www.animalhealthaustralia.com.au/ourpublications/ausvetplan-manuals-anddocuments/accessed on 26 January 2016.

Bannach, O., Birkmann, E., Reinartz, E., Jaeger, K.E., Langeveld, J. P., Rohwer, R. G., Gregori, L., Terry, L.A., Willbold, D. and Riesner, D. 2012. Detection of prion protein particles in blood plasma of scrapie infected sheep. PLoS One. 7, e36620.

Baylis, M., Chihota, C., Stevenson, E., Goldmann, W., Smith, A., Sivam, K., Tongue, S. and Gravenor, M.B. 2004. Risk of scrapie in British sheep of different prion protein genotypes. J. Gen. Virol. 85, 
2735-2740

Bellingham, S.A., Guo, B.B., Coleman, B.M. and Hill, A.F. 2012. Exosomes: vehicles for the transfer of toxic proteins associated with neurodegenerative diseases? Front. Physiol. 3, 124.

Beringue, V., Demoy, M., Lasmezas, C. I., Gouritin, B., Weingarten, C., Deslys, J. P., Andreux, J. P., Couvreur, P. and Dormont, D. 2000. Role of spleen macrophages in the clearance of scrapie agent early in pathogenesis. J. Pathol. 190, 495-502.

Bonita, R., Beaglehole, R. and Kjellström, T. 2006. Basic Epidemiology, $2^{\text {nd }}$ Ed. World Health Organization, Geneva.

Broadbent, D.W. 1972. Listeria as a cause of abortion in sheep. Aust. Vet. J. 48, 391-394.

Brotherston, J.G., Renwick, C.C., Stamp, J.T., Zlotnik, I. and Pattison, I.H. 1968. Spread of scrapie by contact to goats and sheep. J. Comp. Pathol. 78, 917.

Caplazi, P., O’Rourke, K., Wolf, C., Shaw, D. and Baszler, T. V. 2004. Biology of $\operatorname{PrP}^{\mathrm{Sc}}$ accumulation in two natural scrapie-infected sheep flocks. J. Vet. Diagn. Invest. 16, 489-496.

Caughey, B., Baron, G.S., Chesebro, B. and Jeffrey, M. 2009. Getting a grip on prions: oligomers, amyloids, and pathological membrane interactions. Ann. Rev. Biochem. 78, 177-204.

Coetzer, J.A.W., Thomson, G.R. and Tustin, R.C. Eds. 1994. Infectious Diseases of Livestock with Special Reference to Southern Africa. Oxford University Press, Cape Town.

Colby, D.W. and Prusiner, S.B. 2011. De novo generation of prion strains. Nat. Rev. Microbiol. 9, 771-777.

Couquet, C., Cornuejols, M.J., Fremont, A., Allix, S., El Hachimi, K.H., Adjou K.T., Ouidja, M.O., Brugere, H. and Brugere-Picoux, J. 2005. Observation d'un cas de transmission maternelle de la tremblante chez le mouton. B. Acad. Vet. France $158,25-28$.

Dassanayake, R.P., Schneider, D.A., Truscott, T.C., Young, A.J., Zhuang, D. and O'Rourke, K.I. 2011. Classical scrapie prions in ovine blood are associated with B lymphocytes and platelet-rich plasma. BMC Vet. Res. 7, 75.

Dassanayake, R.P., Schneider, D.A., HerrmannHoesing, L.M., Truscott, T.C., Davis, W.C. and O'Rourke, K.I. 2012. Cell-surface expression of $\mathrm{PrP}^{\mathrm{c}}$ and the presence of scrapie prions in the blood of goats. J. Gen. Virol. 93, 1127-1131.

Dennis, M.M., Thomsen, B.V., Marshall, K.L., Hall, S.M., Wagner, B.A., Salman, M.D., Norden, D.K., Gaiser, C. and Sutton, D.L. 2009. Evaluation of immunohistochemical detection of prion protein in rectoanal mucosa-associated lymphoid tissue for diagnosis of scrapie in sheep. Am. J. Vet. Res. 70, 63-72.

Detwiler, L.A. and Baylis, M. 2003. The epidemiology of scrapie. Rev. Sci. Tech. OIE. 22, 121-143.

Dickinson, A.G., Young, G.B., Stamp, J.T. and Renwick, C.C. 1965. An analysis of natural scrapie in Suffolk sheep. Heredity. 20, 485-503.

Dickinson, A.G., Stamp, J.T. and Renwick, C.C. 1974. Maternal and lateral transmission of scrapie in sheep. J. Comp. Pathol. 84, 19-25.

Dubey, J.P. 2009. Toxoplasmosis in sheep - the last 20 years. Vet. Parasitol. 163, 1-14.

Edwards, J.C., Moore, S.J., Hawthorn, J.A., Neale, M.H. and Terry, L.A. 2010. $\operatorname{PrP}(\mathrm{Sc})$ is associated with B cells in the blood of scrapie-infected sheep. Virology 405, 110-119.

EFSA. 2010. EFSA Panel on Biological Hazards (BIOHAZ); Scientific Opinion on Risk of transmission of TSEs via semen and embryo transfer in small ruminants (sheep and goats). EFSA J. 8, 1429-1448.

Elsen, J.M., Amigues, Y., Schelcher, F., Ducrocq, V., Andreoletti, O., Eychenne, F., Khang, J.V., Poivey, J.P., Lantier, F. and Laplanche, J.L. 1999. Genetic susceptibility and transmission factors in scrapie: detailed analysis of an epidemic in a closed flock of Romanov. Arch. Virol. 144, 431-445.

Everest, S.J., Ramsay, A.M., Chaplin, M.J., Everitt, S., Stack, M.J., Neale, M.H., Jeffrey, M.S., Moore, J.S., Bellworthy, J. and Terry, L.A. 2011. Detection and localisation of PrP in the liver of sheep infected with scrapie and bovine spongiform encephalopathy. PLoS One. 6, e19737.

Fast, C. and Groschup, M.H. 2013. Classical and atypical scrapie in sheep and goats. In Prions and Diseases, Volume 2, Animals, Humans and the Environment. Eds. Zou, W-Q. and Gambetti. P. New York: Springer, pp: 15-44.

Foote, W.C., Clark, W., Maciulis, A., Call, J.W., Hourrigan, J., Evans, R.C., Marshall, M.R. and de Camp, M. 1993. Prevention of scrapie transmission in sheep, using embryo transfer. Am. J. Vet. Res. 54, 1863-1868.

Foster, J.D., McKelvey, W.A., Mylne, M.J., Williams, A., Hunter, N., Hope, J. and Fraser, H. 1992. Studies on maternal transmission of scrapie in sheep by embryo transfer. Vet. Rec.130, 341-343.

Foster, J.D., Hunter, N., Williams, A., Mylne, M.J., McKelvey, W.A., Hope, J., Fraser, H. and Bostock, C. 1996. Observations on the transmission of scrapie in experiments using embryo transfer. Vet. Rec.138, 559-562.

Foster, J., McKenzie, C., Parnham, D., Drummond, D., Chong, A., Goldman, W. and Hunter, N. 2006. Lateral transmission of natural scrapie to scrapie- 
free New Zealand sheep placed in an endemically infected UK flock. Vet. Rec. 159, 633-634.

Foster, J.D., Goldmann, W. and Hunter, N. 2013. Evidence in sheep for pre-natal transmission of scrapie to lambs from infected mothers. PLoS One. 8, e79433.

Friedman, G.D. 2004. A Primer of Epidemiology, Fifth Edition. McGraw-Hill Professional, New York.

Galli, S.J., Borregaard, N. and Wynn, T.A. 2011. Phenotypic and functional plasticity of cells of innate immunity: macrophages, mast cells and neutrophils. Nature Immunol. 12, 1035-1044.

Garza, M.C., Fernandez-Borges, N., Bolea, R., Badiola, J.J., Castilla, J. and Monleon, E. 2011. Detection of PrPres in genetically susceptible fetuses from sheep with natural scrapie. PLoS One. 6, e27525.

Gatti, J. L., Metayer, S., Moudjou, M., Andreoletti, O., Lantier, F., Dacheux, J. L. and Sarradin, P. 2002. Prion protein is secreted in soluble forms in the epididymal fluid and proteolytically processed and transported in seminal plasma. Biol. Reprod. 67, 393-400.

Gibbs, C.J.Jr., Gajdusek, D.C. and Harvey, J. 1969. Bibliography on Scrapie. National Institute of Neurological Diseases and Stroke, Bethesda, Maryland.

Goldmann, W. 2008. PrP genetics in ruminant transmissible spongiform encephalopathies. Vet. Res. 39, 30.

Gonzalez, L., Horton, R., Ramsay, D., Toomik, R., Leathers, V., Tonelli, Q., Dagleish, M. P., Jeffrey, M. and Terry, L. 2008. Adaptation and evaluation of a rapid test for the diagnosis of sheep scrapie in samples of rectal mucosa. J. Vet. Diagn. Invest. 20, 203-208.

Gonzalez, L., Martin, S., Siso, S., Konold, T., OrtizPelaez, A., Phelan, L., Goldmann, W., Stewart, P., Saunders, G., Windl, O., Jeffrey, M., Hawkins, S. A., Dawson, M. and Hope, J. 2009. High prevalence of scrapie in a dairy goat herd: tissue distribution of disease-associated PrP and effect of PRNP genotype and age. Vet. Res. 40, 65.

Gonzalez, L., Martin, S., Hawkins, S.A., Goldmann, W., Jeffrey, M. and Siso, S. 2010. Pathogenesis of natural goat scrapie: modulation by host PRNP genotype and effect of co-existent conditions. Vet. Res. 41, 48.

Gonzalez, L., Dagleish, M.P., Martin, S., Finlayson, J., Siso, S., Eaton, S.L., Goldmann, W., Witz, J., Hamilton, S., Stewart, P., Pang, Y., Steele, P., Reid, H.W., Chianini, F. and Jeffrey, M. 2012. Factors influencing temporal variation of scrapie incidence within a closed Suffolk sheep flock. J. Gen. Virol. 93, 203-211.

Gordon, W.S. 1957. Scrapie. Vet. Rec. 69, 1324-1328.
Gordon, W.S. 1966. Variation in susceptibility of sheep to scrapie and genetic implications. In Report of Scrapie Seminar Held At Washington, D.C., January 27-30, 1964. Agricultural Research Service, US Department of Agriculture, 53-68. https://archive.org/stream/report9153scra/report91 53scra_djvu.txt/accessed on 3 August 2015.

Gough, K.C., Baker, C.A., Rees, H.C., Terry, L.A., Spiropoulos, J., Thorne, L. and Maddison, B.C. 2012. The oral secretion of infectious scrapie prions occurs in preclinical sheep with a range of PRNP genotypes. J. Virol. 86, 566-571.

Gough, K.C., Baker, C.A., Simmons, H.A., Hawkins, S.A. and Maddison, B.C. 2015. Circulation of prions within dust on a scrapie affected farm. Vet. Res. 46, 40.

Greig, J.R. 1940. Scrapie: observations on the transmission of the disease by mediate contact. Vet. J. 6, 203-206.

Gustafson, D.P. and Kanitz, C.L. 1966. Long-term cell cultures from brain of sheep affected with scrapie. In Report of Scrapie Seminar Held At Washington, D.C., January 27-30, 1964. Agricultural Research Service, US Department of Agriculture, 69-88. https://archive.org/stream/report9153scra/report91 53scra_djvu.txt/accessed on 3 August 2015.

Hadlow, W.J., Kennedy, R.C. and Race, R.E. 1982. Natural infection of Suffolk sheep with scrapie virus. J. Inf. Dis.146, 657-664.

Hagan, W.H. and Smithcors, J.F. 1964. Veterinary Science. In Encyclopaedia Britannica, Volume 23. Chicago: William Benton, pp: 117-118.

Hansson, S.O. 2013. The Ethics of Risk: Ethical Analysis in an Uncertain World. Palgrave MacMillan.

Hawkins, S.A., Simmons, H.A., Gough, K.C. and Maddison, B.C. 2015. Persistence of ovine scrapie infectivity in a farm environment following cleaning and decontamination. Vet. Rec. 176, 99.

Hedstrom, O.O., Sona, R.J., Lassen, E.D., Hultgren, B.D., Crisman, R.O., Smith, B.B. and Snyder, S.P. 1987. Pathology of Campylobacter jejuni in sheep. Vet. Pathol. 24, 419-426.

Hill, A.B. 1977. A Short Textbook of Medical Statistics. Hodder and Stoughton, London.

Hoinville, L.J. 1996. A review of the epidemiology of scrapie in sheep. Rev. Sci. Tech. OIE. 15, 827-852.

Hoinville, L.J., Tongue, S.C. and Wilesmith, J.W. 2010. Evidence for maternal transmission of scrapie in naturally affected flocks. Prev. Vet. Med. 93, 121-128.

Hourrigan, J., Klingsporn, A. and Clark, W.W. 1979. Epidemiology of Scrapie in the United States. In Slow Transmissible Diseases of the Nervous System, Volume 1. Eds., S.B. Prusiner and W.J. Hadlow. Academic Press, New York, 331-356. 
Houston, E.F., Halliday, S.I., Jeffrey, M., Goldmann, W. and Hunter, N. 2002. New Zealand sheep with scrapie-susceptible PrP genotypes succumb to experimental challenge with a sheep-passaged scrapie isolate (SSBP/1). J. Gen. Virol. 83, 12471250.

Houston, F., McCutcheon, S., Goldmann, W., Chong, A., Foster, J., Siso, S., Gonzalez, L., Jeffrey, M. and Hunter, N. 2008. Prion diseases are efficiently transmitted by blood transfusion in sheep. Blood. 112, 4739-4745.

Huang, F.P., Farquhar, C.F., Mabbott, N.A., Bruce, M.E. and MacPherson, G.G. 2002. Migrating intestinal dendritic cells transport $\mathrm{PrP}^{\mathrm{Sc}}$ from the gut. J. Gen. Virol. 83, 267-271.

Hunter, N., Foster, J.D., Goldmann, W., Stear, M.J., Hope, J. and Bostock, C. 1996. Natural scrapie in a closed flock of Cheviot sheep occurs only in specific PrP genotypes. Arch. Virol. 141, 809-824.

Hunter, N., Foster, J., Chong, A., McCutcheon, S., Parnham, D., Eaton, S., MacKenzie, C. and Houston, F. 2002. Transmission of prion diseases by blood transfusion. J. Gen. Virol. 83, 2897-2905.

Hunter, N. 2007. Scrapie: uncertainties, biology and molecular approaches. Biochim. Biophys. Acta 1772, 619-628.

IETS. 2010. Manual of the International Embryo Transfer Society. International Embryo Transfer Society, Inc. 2441 Village Green Place Champaign, IL 61822.

Janeway, C.A.Jr, Travers, P., Walport, M. and Shlomchik, M.J. 2001. Immunobiology, $5^{\text {th }}$ Ed. Garland Science, New York.

Jeffrey, M. and Gonzalez, L. 2007. Classical sheep transmissible spongiform encephalopathies: pathogenesis, pathological phenotypes and clinical disease. Neuropath. Appl. Neuro. 33, 373-394.

Jeffrey, M., McGovern, G., Goodsir, C. M., Siso, S. and Gonzalez, L. 2009. Strain-associated variations in abnormal PrP trafficking of sheep scrapie. Brain Pathol. 19, 1-11.

Jeffrey, M., McGovern, G., Siso, S. and Gonzalez, L. 2011. Cellular and sub-cellular pathology of animal prion diseases: relationship between morphological changes, accumulation of abnormal prion protein and clinical disease. Acta Neuropathol. 121, 113134.

Johnson, M.L., Grazul-Bilska, A.T., Reynolds, L.P. and Redmer, D.A. 2014. Prion $\left(\mathrm{PrP}^{\mathrm{c}}\right)$ expression in ovine uteroplacental tissues increases after estrogen treatment of ovariectomized ewes and during early pregnancy. Reproduction. 148, 1-10.

Kassirer, J.P., Wong, J.B. and Kopelman, R.I. 2009. Learning Clinical Reasoning $2^{\text {nd }}$ Ed. Wolters Kluwer/Lippincott, Williams and Wilkins.

Katz, J.B., Pedersen, J.C., Jenny, A.L. and Taylor,
W.D. 1992. Assessment of western immunoblotting for the confirmatory diagnosis of ovine scrapie and bovine spongiform encephalopathy (BSE). J. Vet. Diagn. Invest. 4, 447-449.

Khan, K.S., Kunz, R., Kleijnen, J. and Antes, G. 2003. Five steps to conducting a systematic review. J. Roy. Soc. Med. 96, 118-121.

Konold, T., Moore, S.J., Bellworthy, S.J. and Simmons, H.A. 2008. Evidence of scrapie transmission via milk. BMC Vet. Res. 4, 14.

Konold, T., Moore, S.J., Bellworthy, S.J., Terry, L.A., Thorne, L., Ramsay, A., Salguero, F.J., Simmons, M.M. and Simmons, H.A. 2013a. Evidence of effective scrapie transmission via colostrum and milk in sheep. BMC Vet. Res. 9, 99.

Konold, T., Simmons, H.A., Webb, P.R., Bellerby, P.J., Hawkins, S.A. and González, L. 2013 b. Transmission of classical scrapie via goat milk. Vet. Rec. 172, 455.

Lacroux, C., Corbiere, F., Tabouret, G., Lugan, S., Costes, P., Mathey, J., Delmas, J.M., Weisbecker, J.L., Foucras, G., Cassard, H., Elsen, J.M., Schelcher, F. and Andreoletti, O. 2007. Dynamics and genetics of $\mathrm{PrP}^{\mathrm{Sc}}$ placental accumulation in sheep. J. Gen. Virol. 88, 1056-1061.

Lacroux, C., Simon, S., Benestad, S.L., Maillet, S., Mathey, J., Lugan, S., Corbiere, F., Cassard, H., Costes, P., Bergonier, D., Weisbecker, J.L., Moldal, T., Simmons, H., Lantier, F., Feraudet-Tarisse, C., Morel, N., Schelcher, F., Grassi, J. and Andreoletti, O. 2008. Prions in milk from ewes incubating natural scrapie. PLoS Pathog, 4, e1000238.

Lacroux, C., Vilette, D., Fernandez-Borges, N., Litaise, C., Lugan, S., Morel, N., Corbiere, F., Simon, S., Simmons, H., Costes, P., Weisbecker, J. L., Lantier, I., Lantier, F., Schelcher, F., Grassi, J., Castilla, J. and Andreoletti, O. 2012. Prionemia and leukocyteplatelet-associated infectivity in sheep transmissible spongiform encephalopathy models. J. Virol. 86, 2056-2066.

Ligios, C., Cancedda, G.M., Margalith, I., Santucciu, C., Madau, L., Maestrale, Basagni, C., Saba, M. and Heikenwalder, M. 2007. Intraepithelial and interstitial deposition of pathological prion protein in kidneys of scrapie-infected sheep. PLoS One. 2, e859.

Ligios, C., Cancedda, M.G., Carta, A., Santucciu, C., Maestrale, C., Demontis, F., Saba, M., Patta, C., DeMartini, J.C., Aguzzi, A. and Sigurdson, C.J. 2011. Sheep with scrapie and mastitis transmit infectious prions through the milk. J. Virol. 85, 1136-1139.

Low, J.C., Chambers, J., McKelvey, W.A., McKendrick, I.J. and Jeffrey, M. 2009. Failure to transmit scrapie infection by transferring 
preimplantation embryos from naturally infected donor sheep. Theriogenology. 72, 809-816.

Maddison, B.C., Baker, C.A., Rees, H.C., Terry, L.A., Thorne, L., Bellworthy, S.J., Whitelam, G.C. and Gough, K.C. 2009. Prions are secreted in milk from clinically normal scrapie-exposed sheep. J. Virol. 83, 8293-8296.

Maddison, B.C., Rees, H.C., Baker, C.A., Taema, M., Bellworthy, S.J., Thorne, L., Terry, L.A. and Gough, K.C. 2010. Prions are secreted into the oral cavity in sheep with preclinical scrapie. J. Infect. Dis. 201, 1672-1676.

McGovern, G. and Jeffrey, M. 2013. Membrane toxicity of abnormal prion protein in adrenal chromaffin cells of scrapie infected sheep. PLoS One. 8, e58620

Miller, J.M., Jenny, A.L., Taylor, W.D., Marsh, R.F., Rubenstein, R. and Race, R.E. 1993. Immunohistochemical detection of prion protein in sheep with scrapie. J. Vet. Diagn. Invest. 5, 309316.

Monleon, E., Garza, M.C., Sarasa, R., AlvarezRodriguez, J., Bolea, R., Monzon, M., Vargas, M. A., Badiola, J.J. and Acin, C. 2011. An assessment of the efficiency of $\mathrm{PrP}^{\mathrm{Sc}}$ detection in rectal mucosa and third-eyelid biopsies from animals infected with scrapie. Vet. Microbiol. 147, 237-243.

Nardone, D.A. 1990. Collecting and Analyzing Data: Doing and Thinking. In Clinical Methods, The History, Physical, and Laboratory Examination, 3rd edition. Eds. Walker, H.K., Hall, W.D. and Hurst, J.W.

Butterworths, http://www.ncbi.nlm.nih.gov/books/NBK201/.

Nettleton, P.F., Gilray, J.A., Russo, P. and Dlissi, E. 1998. Border disease of sheep and goats. Vet. Res. 27, 327-340.

Oehlert, G.W. 2000. A First Course in the Design and Analysis of Experiments. W.H. Freeman and Company, New York.

OIE. 2011. Scrapie, Chapter 2.7.13. In OIE Terrestrial Manual. World Organisation for Animal Health, Paris. http://www.oie.int/en./ accessed on 3 June 2015.

OIE. 2015. OIE Terrestrial Animal Code. World Organisation for Animal Health, Paris. http://www.oie.int/en./ accessed on 3 June 2015.

Onodera, T., Ikeda, T., Muramatsu, Y. and Shinagawa, M. 1993. Isolation of scrapie agent from the placenta of sheep with natural scrapie in Japan. Microbiol. Immunol. 37, 311-316.

O'Rourke, K.I., Baszler, T.V., Besser, T.E., Miller, J.M., Cutlip, R.C., Wells, G.A., Ryder, S.J., Parish, S.M., Hamir, A.N., Cockett, N.E., Jenny, A. and Knowles, D.P. 2000. Preclinical diagnosis of scrapie by immunohistochemistry of third eyelid lymphoid tissue. J. Clin. Microbiol. 38, 3254-3259.
O’Rourke, K.I., Duncan, J.V., Logan, J.R., Anderson, A.K., Norden, D.K., Williams, E.S., Combs, B.A., Stobart, R.H., Moss, G.E. and Sutton, D.L. 2002. Active surveillance for scrapie by third eyelid biopsy and genetic susceptibility testing of flocks of sheep in Wyoming. Clin. Diagn. Lab. Immunol. 9, 966-971.

O’Rourke, K., Zhuang, D., Truscott, T., Yan, H. and Schneider, D. 2011. Sparse $\operatorname{PrP}^{\mathrm{Sc}}$ accumulation in the placentas of goats with naturally acquired scrapie. BMC Vet. Res. 7, 7.

Ott, T.L. and Gifford, C.A. 2010. Effects of early conceptus signals on circulating immune cells: lessons from domestic ruminants. Am. J. Reprod. Immunol. 64, 245-254.

Palmer, A.C. 1959. Attempt to transmit scrapie by injection of semen from an affected ram. Vet. Rec. $71,664$.

Parry, H.B. 1962. Scrapie: a transmissible and hereditary disease of sheep. Heredity. 17, 75105.

Parry, H.B. 1983. Scrapie Disease in Sheep: Historical, Epidemiological, Pathological and Practical Aspects of the Natural Disease. Ed. D.R. Oppenheimer. Academic Press, London.

Pattison, I.H., Hoare, M.N., Jebbett, J.N. and Watson, W.A. 1972. Spread of scrapie to sheep and goats by oral dosing with foetal membranes from scrapieaffected sheep. Vet. Rec. 90, 465-468.

Pattison, I.H., Hoare, M.N., Jebbett, J.N. and Watson, W.A. 1974. Further observations on the production of scrapie in sheep by oral dosing with foetal membranes from scrapie-affected sheep. Brit. Vet. J. 130, lxv-lxvii.

Paul, W.E. 2013. Fundamental Immunology 7th Ed. Wolters Kluwer Health/Lippincott Williams and Wilkins, Philadelphia.

Peralta, O.A., Huckle, W.R. and Eyestone, W.H. 2012. Developmental expression of the cellular prion protein $\left(\mathrm{PrP}^{\mathrm{c}}\right)$ in bovine embryos. Mol. Reprod. Dev. 79, 488-498.

Petticrew, M. and Roberts, H. 2006. Systematic reviews in the social sciences: a practical guide. Blackwell Publishing, Oxford.

Porta, M. 2014. A Dictionary of Epidemiology. Oxford University Press, Oxford.

Press, C.M., Heggebo, R. and Espenes, A. 2004. Involvement of gut-associated lymphoid tissue of ruminants in the spread of transmissible spongiform encephalopathies. Adv. Drug Deliv. Rev. 56, 885899.

Prusiner, S.B. 1998, Prions. Proc. Natl. Acad. Sci. U S A. $95,13363-13383$.

Prusiner, S.B. 2013. Biology and genetics of prions causing neurodegeneration. Ann. Rev. Genet. 47, 601-623. 
Race, R., Jenny, A. and Sutton, D. 1998. Scrapie infectivity and proteinase K-resistant prion protein in sheep placenta, brain, spleen, and lymph node: implications for transmission and antemortem diagnosis. J. Infect. Dis. 178, 949-953.

Radostits, O.M., Tyler, J.W. and Mayhew, I.G. 2000. Making a diagnosis. In Veterinary Clinical Examination and Diagnosis. Eds. Radostits, O.M., Mayhew, I.G. and Houston, D.M. London: W.B. Saunders, pp: 11-49.

Redman, C.A., Coen, P.G., Matthews, L., Lewis, R.M., Dingwall, W.S., Foster, J.D., Chase-Topping, M.E., Hunter, N. and Woolhouse, M.E. 2002. Comparative epidemiology of scrapie outbreaks in individual sheep flocks. Epidemiol. Infect. 128, 513-521.

Robertson, S.A. 2000. Control of the immunological environment of the uterus. Rev. Reprod. 5, 164-174.

Rubenstein, R., Chang, B., Gray, P., Piltch, M., Bulgin, M. S., Sorensen-Melson, S. and Miller, M. W. 2010. A novel method for preclinical detection of $\mathrm{PrP}^{\mathrm{Sc}}$ in blood. J. Gen. Virol. 91, 1883-1892.

Rubenstein, R., Bulgin, M.S, Chang, B., SorensenMelson, S., Petersen, R.B. and Lafauci, G. 2012. $\mathrm{PrP}^{\mathrm{Sc}}$ detection and infectivity in semen from scrapie-infected sheep. J. Gen. Virol. 93, 13751383.

Ruxton, G.D. and Colegrave, N. 2006. Experimental Design for the Life Sciences, Second Edition, Oxford University Press, Oxford.

Ryder, S., Dexter, G., Bellworthy, S. and Tongue, S. 2004. Demonstration of lateral transmission of scrapie between sheep kept under natural conditions using lymphoid tissue biopsy. Res. Vet. Sci. 76, 211-217.

Ryder, S.J., Dexter, G.E., Heasman, L., Warner, R. and Moore, S.J. 2009. Accumulation and dissemination of prion protein in experimental sheep scrapie in the natural host. BMC Vet. Res. 5, 9.

Saa, P., Castilla, J. and Soto, C. 2005. Cyclic amplification of protein misfolding and aggregation. Methods Mol. Biol. 299, 53-65.

Santucciu, C., Maestrale, C., Madau, L., Attene, S., Cancedda, M.G., Demontis, F. Tilocca, M.G., Saba, M., Macciocu, S., Carta, A. and Ligios, C. 2010. Association of N176K and L141F dimorphisms of the PRNP gene with lack of pathological prion protein deposition in placentas of naturally and experimentally scrapie-affected ARQ/ARQ sheep. J. Gen. Virol. 91, 2402-2407.

Sarradin, P., Melo, S., Barc, C., Lecomte, C., Andreoletti, O., Lantier, F., Dacheux, J.L. and Gatti, J.L. 2008. Semen from scrapie-infected rams does not transmit prion infection to transgenic mice. Reproduction. 135, 415-418.
Schneider, D.A., Madsen-Bouterse, S.A., Zhuang, D., Truscott, T.C., Dassanayake, R.P. and O'Rourke, K.I. 2015. The placenta shed from goats with classical scrapie is infectious to goat kids and lambs. J. Gen. Virol. 96, 2464-2469.

Schreuder, B.E., van Keulen, L.J., Vromans, M.E., Langeveld, J.P. and Smits, M.A. 1998. Tonsillar biopsy and $\mathrm{PrP}^{\mathrm{Sc}}$ detection in the preclinical diagnosis of scrapie. Vet. Rec. 142, 564-568.

Scott, J.L., Ketheesan, N. and Summers, P.M. 2006. Leucocyte population changes in the reproductive tract of the ewe in response to insemination Reprod. Fertil. Dev.18, 627-634.

Scott, J.L., Ketheesan, N. and Summers, P.M. 2009. Spermatozoa and seminal plasma induce a greater inflammatory response in the ovine uterus at oestrus than dioestrus. Reprod. Fertil. Dev., 21, 817-826.

Smith, J.B., McIntosh, G.H. and Morris, B. 1970. The traffic of cells through tissues: a study of peripheral lymph in sheep. J. Anat. 107. 87-100.

Soto, C. 2012. Transmissible proteins: expanding the prion heresy. Cell 149, 968-977.

Spiropoulos, J., Hawkins, S.A.C., Simmons, M.M. and Bellworthy, S.J. 2014. Evidence of in utero transmission of classical scrapie in sheep. J. Virol. 88, 4591-4594.

Staples, L.D., Fleet, I.R. and Heap, R.B. 1982. Anatomy of the utero-ovarian lymphatic network and the composition of afferent lymph in relation to the establishment of pregnancy in the sheep and goat. J. Reprod. Fertil. 64, 409-420.

Supattapone, S. 2015. Expanding the prion disease repertoire. Proc. Natl. Acad. Sci. U S A. 112, 11748-11749.

Terry, L.A., Howells, L., Hawthorn, J., Edwards, J.C., Moore, S.J., Bellworthy, S.J., Simmons, H., Lizano, S., Estey, L., Leathers, V. and Everest, S.J. 2009. Detection of $\mathrm{PrP}^{\mathrm{Sc}}$ in blood from sheep infected with the scrapie and bovine spongiform encephalopathy agents. J. Virol. 83, 12552-12558.

Terry, L.A., Howells, L., Bishop, K., Baker, C.A., Everest, S., Thorne, L., Maddison, B.C. and Gough, K.C. 2011. Detection of prions in the faeces of sheep naturally infected with classical scrapie. Vet. Res. 42, 65.

Thorne, L. and Terry, L. A. 2008. In vitro amplification of $\mathrm{PrP}^{\mathrm{Sc}}$ derived from the brain and blood of sheep infected with scrapie. J. Gen. Virol. 89, 31773184.

Thumdee, P., Ponsuksili, S., Murani, E., Nganvongpanit, K., Gehrig, B., Tesfaye, D., Gilles, M., Hoelker, M., Jennen, D., Griese, J., Schellander, K. and Wimmers, K. 2007. Expression of the prion protein gene (PRNP) and cellular prion protein $\left(\mathrm{PrP}^{\mathrm{c}}\right)$ in cattle and sheep fetuses and 
maternal tissues during pregnancy. Gene Expr. 13, 283-297.

Toppets, V., Defaweux, V., Piret, J., Kirschvink, N., Grobet, L. and Antoine, N. 2011. Features of follicular dendritic cells in ovine pharyngeal tonsil: an in vivo and in vitro study in the context of scrapie pathogenesis. Vet. Immunol. Immunopathol. 141, 26-32.

Tuo, W., Zhuang, D., Knowles, D.P., Cheevers, W.P., Sy, M.S. and O'Rourke, K.I. 2001. $\operatorname{Prp}^{c}$ and $\operatorname{Prp}^{\text {Sc }}$ at the fetal-maternal interface. J. Biol. Chem. 276, 18229-18234.

Tuo, W., O’Rourke, K.I., Zhuang, D., Cheevers, W.P., Spraker, T.R. and Knowles, D.P. 2002. Pregnancy status and fetal prion genetics determine $\operatorname{PrP}^{\mathrm{Sc}}$ accumulation in placentomes of scrapie-infected sheep. Proc. Natl. Acad. Sci. USA. 99, 6310-6315.

Ulvund, M.J. 2008. Ovine scrapie disease: Do we have to live with it? Small Ruminant Res. 76, 131-140.

US Department of Health and Human Services. 2013. Self-Study Course SS1000, Principles of Epidemiology in Public Health Practice, Third Edition.

www.cdc.gov/ophss/csels/dsepd/ss1978/ss1978.pd f.

van Keulen, L.J., Schreuder, B.E., Meloen, R.H., Mooij-Harkes, G., Vromans, M.E. and Langeveld, J. P. 1996. Immunohistochemical detection of prion protein in lymphoid tissues of sheep with natural scrapie. J. Clin. Microbiol. 34, 1228-1231.

van Keulen, L.J., Bossers, A. and van Zijderveld, F. 2008. TSE pathogenesis in cattle and sheep. Vet. Res. 39, 24.

Vascellari, M., Nonno, R., Mutinelli, F., Bigolaro, M., Di Bari, M.A., Melchiotti, E., Marcon, S., D’Agostino, C., Vaccari, G., Conte, M., De Grossi, L., Rosone, F., Giordani, F. and Agrimi, U. 2007. $\mathrm{PrP}^{\mathrm{Sc}}$ in salivary glands of scrapie-infected sheep. J. Virol. 81, 4872-4876.

Wang, S., Foote, W.C., Sutton, D.L., Maciulis, A., Miller, J.M., Evans, R.C., Holyoak, G.R., Call, J.W., Bunch, T.D., Taylor, W.D. and Marshall, M.R. 2001. Preventing experimental vertical transmission of scrapie by embryo transfer. Theriogenology 56, 315-327.

Wang, S., Cockett, N.E., Miller, J.M., Shay, T.L., Maciulis, A., Sutton, D.L., Foote, W.C., Holyoak, G.R., Evans, R.C., Bunch, T.D., Beever, J.E., Call, J.W., Taylor, W.D. and Marshall, M.R. 2002. Polymorphic distribution of the ovine prion protein (PrP) gene in scrapie-infected sheep flocks in which embryo transfer was used to circumvent the transmissions of scrapie. Theriogenology. 57, 18651875.

Zar, J.H. 1996. Biostatistical Analysis $3^{\text {rd }}$ Ed. PrenticeHall, Upper Saddle River, New Jersey. 